\title{
molecules
}

ISSN 1420-3049

www.mdpi.com/journal/molecules

Article

\section{Investigation of the Biological Properties of (Hetero)Aromatic Thiosemicarbazones}

Maciej Serda ${ }^{1}$, Anna Mrozek-Wilczkiewicz ${ }^{1,2}$, Josef Jampilek ${ }^{3,4}$, Matus Pesko ${ }^{5}$, Katarina Kralova ${ }^{6}$, Marcela Vejsova ${ }^{7}$, Robert Musiol ${ }^{1, *}$, Alicja Ratuszna ${ }^{2}$ and Jaroslaw Polanski ${ }^{1}$

1 Department of Organic Chemistry, Institute of Chemistry, University of Silesia, PL-40006 Katowice, Poland

2 Institute of Physics, University of Silesia, PL-40007 Katowice, Poland

3 Department of Chemical Drugs, Faculty of Pharmacy, University of Veterinary and Pharmaceutical Sciences, Palackeho 1/3, CZ-61242 Brno, Czech Republic

4 Research Institute for Pharmacy and Biochemistry, Lidicka 1879/48, CZ-60200 Brno, Czech Republic

5 Department of Ecosozology and Physiotactics, Faculty of Natural Sciences, Comenius University, Mlynska dolina Ch-2, SK-84215 Bratislava, Slovakia

6 Institute of Chemistry, Faculty of Natural Sciences, Comenius University, Mlynska dolina Ch-2, SK-84215 Bratislava, Slovakia

7 Department of Clinical Microbiology, Charles University Medical School and Teaching Hospital, Sokolska 581, CZ-50005 Hradec Kralove, Czech Republic

* Author to whom correspondence should be addressed; E-Mail: robert.musiol@us.edu.pl; Tel.: +48-032-359-1514.

Received: 8 October 2012; in revised form: 7 November 2012 / Accepted: 8 November 2012 / Published: 14 November 2012

Abstract: Two series of thiosemicarbazone-based iron chelators (twenty-seven compounds) were designed and synthesized using a microwave-assisted approach. Quinoline and halogenated phenyl were selected as parent scaffolds on the basis of a similarity search. The lipophilicity of the synthesized compounds was measured using HPLC and then calculated. Primary in vitro screening of the synthesized compounds was performed against eight pathogenic fungal strains. Only a few compounds showed moderate activity against fungi, and (E)-2-(quinolin-2-ylvinyl)- $N, N$-dimethylhydrazinecarbothioamide appeared to be more effective than fluconazole against most of the fungal strains tested. Antiproliferative activity was measured using a human colon cancer cell line 
(HCT-116). Several of the tested compounds showed submicromolar antiproliferative activity. Compounds were also tested for their activity related to the inhibition of photosynthetic electron transport (PET) in spinach (Spinacia oleracea L.) chloroplasts. The structure-activity relationships are discussed for all of the compounds.

Keywords: thiosemicarbazones; lipophilicity; photosynthetic electron transport inhibition; spinach chloroplasts; iron chelators; in vitro antifungal activity; in vitro anticancer activity

\section{Introduction}

Iron is an element of great importance for virtually all living organisms. It is present in various biological processes such as metabolic pathways, reproduction or photosynthesis. On the basis of its importance, the iron-sulphur theory of the origin of life has been proposed [1,2]. Despite being so pervasive, iron rarely exists alone or in the form of simple cations. It is commonly chelated by larger organic molecules such as porphyrin. This form is present in hemoglobin or in most of the metabolic enzymes of cytochrome $\mathrm{P}_{450}$ [3]. Clearly, all living organisms have their ways of acquiring and managing such an important element. Any alteration of or damage to the iron metabolism system may lead to serious diseases. In humans, this may cause hemochromatosis or iron deficiency anemia [4]. As a target for therapy, iron is used mainly in the treatment of iron overload using iron chelators such as deferoxamine (DFO, also known as desferrioxamine B) [5]. More recently, iron chelators have been proposed for cancer treatment [5-10] because rapidly proliferating cancer cells have a higher demand for this element compared to the normal cells $[5,11]$. Although the exact mechanism of the anticancer activity of iron chelators remains unknown, several possible modes of action can be implemented, e.g., the inhibition of iron uptake [12] and the inhibition of ribonucleotide reductase (RR) [13] or the formation of reactive oxygen species (ROS) [14].

Other potential therapeutic or agricultural application of iron chelators may be derived from processes or pathways that are dependent on iron in pathological organisms. Fungi and bacteria require an appropriate amount of iron for correct growth, and apparently to develop their resistance to drugs $[15,16]$. Pathogenic microbes have evolved their unique way of acquiring this important metal from a host organism through the overexpression of Fe receptors or the utilization of siderophores [17]. If the iron level is reduced, fungi lose some of their virulence and have a decreased potency to invade the epithelium. Hence, lactoferrin and deferoxamine have been tested for their antifungal potency. Early attempts have consisted in the co-administration of lactoferrin with conventional antifungals such as amphotericin B [18,19]. DFO was tested as an ancillary drug with amphotericin B in antifungal therapy in a clinical trial [20,21]. The study was terminated prematurely due to an increased mortality in patients who had taken DFO when compared to those who had taken a placebo. However, this seems to be an effect of the more complex prerequisites connected with the unknown site of administration of DFO rather than with synergic toxicity. Nevertheless, this is a trigger to search for structurally new iron chelators with an antifungal activity. Several reports describing the synthesis and antifungal activity of thiosemicarbazones have been published [22-26]. Li et al. described a series of benzyl thiosemicarbazones whose substitution with a chlorine atom triggered the activity of mushroom 
tyrosinase [27]. Moreover, chlorine derivatives of benzaldehyde 4-phenyl-3-thiosemicarbazone and their cyclization products were tested against Toxoplasma gondii and several bacterial strains [28]. Some of these derivatives were more active than chloramphenicol and rifampicin.

In this paper, some disubstituted benzaldehyde thiosemicarbazones are described along with their anticancer and antifungal activity. These structures were tested on the basis of a former study on antifungal compounds [29-33] and quinolone-based thiosemicarbazones with anticancer activity [34]. Figure 1 illustrates the fragment-based similarity of the compounds investigated with known and effective iron chelators [5,35-37]. The design of compounds with polypharmacological activity was the aim of our investigation. Such compounds may be of great value in anticancer therapy where fungal infections are very common. Furthermore, these compounds, due to their simple and cheap synthesis, are suitable for agricultural use. However, antifungal agents such as azoles used for crop protection raise some concerns, e.g., triggering resistance [38] and have a negative impact on the environment. In fact, iron is also important in plants where it plays a crucial role in photosystems I and II as a part of ferredoxin [39] and cytochrome b559 [40-43]. Taking this aspect into account, thiosemicarbazone iron chelators may exert some unwanted effects on the green parts of plants. Thus, the compounds prepared for the inhibition of photosynthetic electron transport were also tested.

Figure 1. (A) Structures of known iron chelators 3-AP [5], 311 [35], Dp44mT [36,37]. (B) investigated benzylidenethiosemicarbazones 3a-o, quinolinylvinylthiosemicarbazones $4 \mathbf{a}-\mathbf{l}$.

A

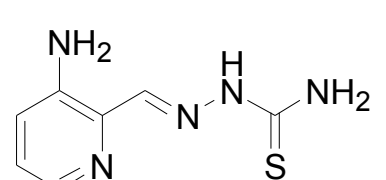

3-aminopyridine-2-carboxaldehyde thiosemicarbazone (triapine, 3-AP)

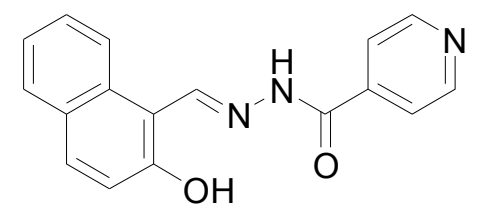

2-hydroxy-1-naphthaldehyde isonicotinoyl hydrazone (311)

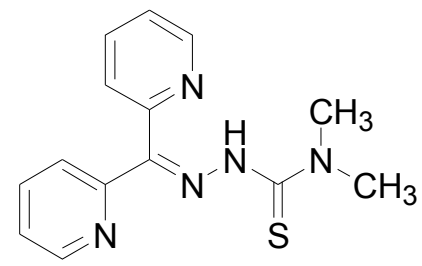

di-2-pyridylketone 4,4-dimethyl3-thiosemicarbazone (Dp44mT)

B<smiles>[R]NC(=S)NN=Cc1cccc(Cl)c1Cl</smiles>

3a-e<smiles>[R]N([R])C(=S)NN=Cc1ccc(Cl)c(Cl)c1</smiles>

$3 f-j$

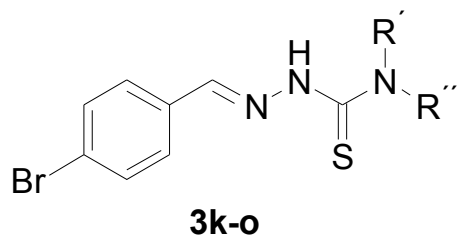

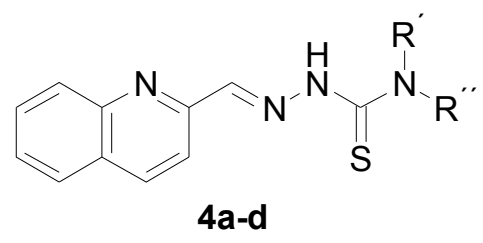
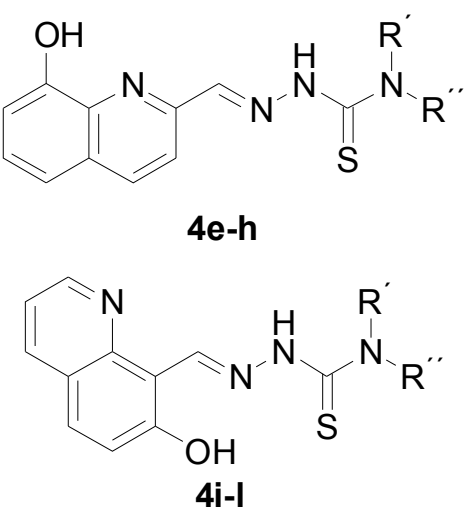


\section{Results and Discussion}

\subsection{Chemistry}

Compounds 3a-o were obtained as shown in Scheme 1. Microwave irradiation was found to be helpful for enhancing the yield of the syntheses and the purity of the final products (the purity of all of the compounds was assessed using HPLC and was higher than $98 \%$, while the overall average yield exceeded $80 \%$ ). All of the synthesized compounds were in the $E$-configuration, which was confirmed using ${ }^{1} \mathrm{H}-\mathrm{NMR}$ spectroscopy (the signal of the $\mathrm{NH}$ group was in the 10-11 ppm range, in comparison to $Z$-isomer, which possesses a characteristic NH signal in the 14-15 ppm range), the COSY and NOESY experiments and by crystal structure as was reported recently [44]. Exemplary spectra are available in Supplementary Material for this article.

Scheme 1. Synthesis of the discussed benzylidenethiosemicarbazones $\mathbf{3 a}-\mathbf{0}$ and quinolinylvinylthiosemicarbazones $\mathbf{4 a - 1}$.

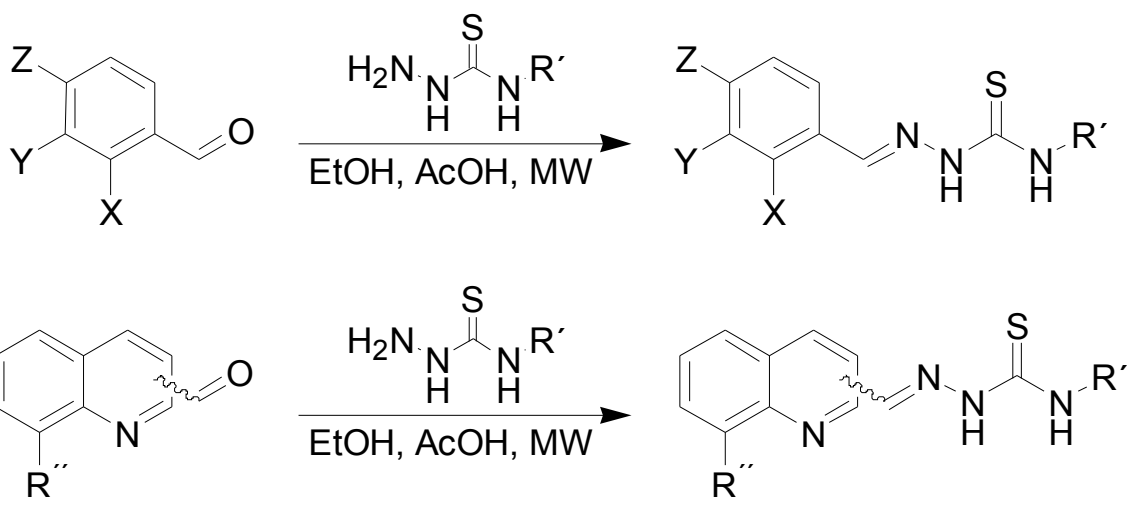

\subsection{Lipophilicity}

Lipophilicity is a property that has a major effect on absorption, distribution, metabolism, excretion and toxicity properties as well as on pharmacological activity because drugs cross biological membranes through passive transport, which is strongly dependent on their lipophilicity. Lipophilicity has been studied and applied as an important drug property for decades. The lipophilicity of the compounds studied was determined using RP-HPLC as a capacity factor logarithm $(\log k)$ and calculated as $\log P / \mathrm{Clog} P$ using two commercially available software programs (ChemOffice and $\mathrm{ACD} / \log \mathrm{P})[45,46]$. The results for benzylidenethiosemicarbazones $\mathbf{3 a}-\mathbf{0}$ are shown in Table 1 , they are summarized for quinolinylvinylthiosemicarbazones $\mathbf{4 a - 1}$ in Table 2 and are illustrated for both series in Figure 2.

Reversed phase high performance liquid chromatography (RP-HPLC) methods have become popular and are widely used for lipophilicity measurements. The general procedure is the measurement of the directly accessible retention time under isocratic conditions using varying amounts of methanol as an organic modifier in the mobile phase using RP columns and calculating the logarithm of the capacity factors $(\log k)$. Log $k$ is the logarithm of the capacity factors in chromatographic approaches that is related to the partitioning of a compound between a mobile and a (pseudo-)stationary phase. $\log k$ is used as the lipophilicity index converted to $\log P$ scale. 
Table 1. Structure of aryl compounds 3a-o and comparison of the calculated lipophilicities $(\log P / C \log P)$ with determined $\log k$ values.

\begin{tabular}{|c|c|c|c|c|c|c|}
\hline \multirow[b]{2}{*}{ Comp. } & \multirow[b]{2}{*}{$\mathbf{R}^{1}$} & \multicolumn{2}{|c|}{$\mathrm{R}^{1} \frac{\sqrt{1}}{11}$} & \multicolumn{2}{|r|}{$\begin{array}{l}\mathrm{R}^{2} \\
\mathrm{~N} \\
\mathrm{R}^{3}\end{array}$} & \multirow[b]{2}{*}{$\begin{array}{c}\log \boldsymbol{P} \\
\mathrm{ACD} / \log \mathrm{P} \\
\end{array}$} \\
\hline & & $\mathbf{R}^{2}$ & $\mathbf{R}^{3}$ & $\log k$ & $\begin{array}{c}\log P / C \log P \\
\text { ChemOffice }\end{array}$ & \\
\hline $3 a$ & $2,3-\mathrm{Cl}$ & $\mathrm{H}$ & $\mathrm{H}$ & 0.6892 & $2.81 / 3.473$ & $3.22 \pm 0.38$ \\
\hline $3 b$ & $2,3-\mathrm{Cl}$ & $\mathrm{H}$ & $\mathrm{CH}_{3}$ & 0.7357 & $3.33 / 3.177$ & $3.14 \pm 0.59$ \\
\hline $3 \mathbf{c}$ & $2,3-\mathrm{Cl}$ & $\mathrm{CH}_{3}$ & $\mathrm{CH}_{3}$ & 0.7214 & $3.71 / 3.533$ & $3.11 \pm 0.60$ \\
\hline 3d & $2,3-\mathrm{Cl}$ & $\mathrm{H}$ & $\mathrm{C}_{2} \mathrm{H}_{5}$ & 0.7958 & $3.67 / 3.706$ & $3.68 \pm 0.59$ \\
\hline $3 e$ & $2,3-\mathrm{Cl}$ & $\mathrm{H}$ & $\mathrm{C}_{6} \mathrm{H}_{5}$ & 0.9230 & $5.00 / 5.266$ & $4.90 \pm 0.59$ \\
\hline $3 f$ & $3,4-\mathrm{Cl}$ & $\mathrm{H}$ & $\mathrm{H}$ & 0.6974 & $2.81 / 3.473$ & $3.28 \pm 0.38$ \\
\hline $3 g$ & $3,4-\mathrm{Cl}$ & $\mathrm{H}$ & $\mathrm{CH}_{3}$ & 0.7563 & $3.33 / 3.177$ & $3.21 \pm 0.59$ \\
\hline $3 \mathbf{h}$ & $3,4-\mathrm{Cl}$ & $\mathrm{CH}_{3}$ & $\mathrm{CH}_{3}$ & 0.7555 & $3.71 / 3.533$ & $3.17 \pm 0.60$ \\
\hline $3 \mathbf{i}$ & $3,4-\mathrm{Cl}$ & $\mathrm{H}$ & $\mathrm{C}_{2} \mathrm{H}_{5}$ & 0.8415 & $3.67 / 3.706$ & $3.74 \pm 0.59$ \\
\hline $3 \mathbf{j}$ & $3,4-\mathrm{Cl}$ & $\mathrm{H}$ & $\mathrm{C}_{6} \mathrm{H}_{5}$ & 0.9774 & $5.00 / 5.266$ & $4.96 \pm 0.59$ \\
\hline $3 k$ & $4-\mathrm{Br}$ & $\mathrm{H}$ & $\mathrm{H}$ & 0.6580 & $2.53 / 2.952$ & $2.79 \pm 0.39$ \\
\hline 31 & $4-\mathrm{Br}$ & $\mathrm{H}$ & $\mathrm{CH}_{3}$ & 0.6993 & $3.05 / 2.734$ & $2.72 \pm 0.61$ \\
\hline $3 m$ & $4-\mathrm{Br}$ & $\mathrm{CH}_{3}$ & $\mathrm{CH}_{3}$ & 0.6784 & $3.42 / 3.090$ & $2.68 \pm 0.62$ \\
\hline $3 n$ & $4-\mathrm{Br}$ & $\mathrm{H}$ & $\mathrm{C}_{2} \mathrm{H}_{5}$ & 0.7568 & $3.39 / 3.263$ & $3.25 \pm 0.61$ \\
\hline 30 & $4-\mathrm{Br}$ & $\mathrm{H}$ & $\mathrm{C}_{6} \mathrm{H}_{5}$ & 0.8772 & $4.71 / 4.823$ & $4.47 \pm 0.61$ \\
\hline
\end{tabular}

Commercially available chemical software does not resolve the various lipophilicity values of individual positional isomers, etc. The software calculates lipophilicity contributions according to different internal databases/libraries and uses different approaches. It can be concluded that for small, highly functionalized molecules with many heteroatoms, a number of intermolecular forces and intramolecular interactions are typical. The more of these interactions that can be expected, the less the predictability of common software can be, thus experimental lipophilicity determination is of great importance. Therefore, we decided to perform our measurements using the water-methanol system as the mobile phase. Log $k$ derived from RP-HPLC retention factors and computational $\log P$ values are given in the manuscript and biological data are related to $\log k$ data because $\log k$ data specify lipophilicity within the series of compounds more precisely than the available chemical software.

The results obtained with all the compounds show that the experimentally-determined lipophilicities $(\log k)$ of the compounds discussed are relatively in accordance with the calculated values of compounds $\mathbf{3 a}-\mathbf{0}$ and $\mathbf{4 a}-\mathbf{I}$ as is shown in Figure 2. The minimum match of experimental $(\log k)$ versus calculated $(\log P$ ) values was found for ChemOffice. Generally, benzylidenethiosemicarbazones 3a-o showed a higher match (see Figure 2A) than quinolinylvinylthiosemicarbazones $\mathbf{4 a - 1}$ (see Figure 2B), which indicates inter- and intramolecular interactions in the last mentioned series. 
Table 2. Structure of heteroaryl compounds $\mathbf{4 a - 1}$ and comparison of calculated lipophilicities $(\log P / C \log P)$ with determined $\log k$ values.

\begin{tabular}{|c|c|c|c|c|c|c|}
\hline \multirow[b]{2}{*}{ Comp. } & \multirow[b]{2}{*}{$\mathbf{R}^{1}$} & \multicolumn{3}{|c|}{ 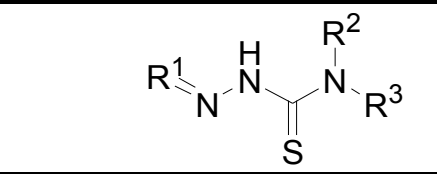 } & \multirow[b]{2}{*}{$\begin{array}{l}\log P / C \log P \\
\text { ChemOffice }\end{array}$} & \multirow[b]{2}{*}{$\begin{array}{c}\log \boldsymbol{P} \\
\mathrm{ACD} / \log \mathrm{P}\end{array}$} \\
\hline & & $\mathbf{R}^{2}$ & $\mathbf{R}^{3}$ & $\log k$ & & \\
\hline $4 a$ & & $\mathrm{H}$ & $\mathrm{CH}_{3}$ & 0.6329 & $2.73 / 1.968$ & $2.06 \pm 0.59$ \\
\hline $4 b$ & & $\mathrm{CH}_{3}$ & $\mathrm{CH}_{3}$ & 0.6184 & $3.10 / 2.114$ & $2.02 \pm 0.60$ \\
\hline $4 c$ & & $\mathrm{H}$, & $\mathrm{C}_{2} \mathrm{H}_{5}$ & 0.6892 & $3.06 / 2.497$ & $2.59 \pm 0.59$ \\
\hline 4d & & $\mathrm{H}$ & $\mathrm{C}_{6} \mathrm{H}_{5}$ & 0.7553 & $4.39 / 4.057$ & $3.81 \pm 0.59$ \\
\hline $4 e$ & & $\mathrm{H}$ & $\mathrm{CH}_{3}$ & 0.6236 & $2.34 / 2.064$ & $1.85 \pm 0.84$ \\
\hline $4 f$ & & $\mathrm{CH}_{3}$ & $\mathrm{C}_{6} \mathrm{H}_{5}$ & 0.5927 & $2.71 / 2.163$ & $1.81 \pm 0.85$ \\
\hline $4 g$ & & $\mathrm{H}$ & $\mathrm{C}_{2} \mathrm{H}_{5}$ & 0.6810 & $2.67 / 2.593$ & $2.38 \pm 0.84$ \\
\hline $4 h$ & & $\mathrm{H}$ & $\mathrm{C}_{6} \mathrm{H}_{5}$ & 0.7548 & $4.00 / 4.153$ & $3.60 \pm 0.84$ \\
\hline $4 i$ & & $\mathrm{H}$ & $\mathrm{CH}_{3}$ & 0.6193 & $1.91 / 2.131$ & $1.62 \pm 1.09$ \\
\hline $4 j$ & & $\mathrm{CH}_{3}$ & $\mathrm{CH}_{3}$ & 0.5831 & $2.29 / 2.163$ & $1.58 \pm 1.10$ \\
\hline $4 k$ & & $\mathrm{H}$ & $\mathrm{C}_{2} \mathrm{H}_{5}$ & 0.6539 & $2.25 / 2.660$ & $2.15 \pm 1.09$ \\
\hline 41 & & $\mathrm{H}$ & $\mathrm{C}_{6} \mathrm{H}_{5}$ & 0.6748 & $3.58 / 4.220$ & $3.37 \pm 1.09$ \\
\hline
\end{tabular}

Lipophilicity calculations of these small and highly functionalized molecules do not cover interand intramolecular interactions that can be found by experimental lipophilicity determination. As was expected, quinolinylvinylthiosemicarbazones $4 \mathbf{4}-\mathbf{l}$ showed a lower lipophilicity $(\log k)$ than benzylidene-thiosemicarbazones 3a-o. Within the series of benzylidenethiosemicarbazones, the determined $\log k$ values increased as follows: 4- $\mathrm{Br}(\mathbf{3 k}-\mathbf{0})<2,3-\mathrm{Cl}(\mathbf{3 a}-\mathbf{e})<3,4-\mathrm{Cl}(\mathbf{3} \mathbf{f}-\mathbf{j})$, while within the series of quinolinylvinylthiosemicarbazones, the determined $\log k$ values increased in the following order: 7-hydroxyquinolin-8-yl (4i-1) $<$ 8-hydroxyquinolin-2-yl (4e--h) $<$ quinoline-2-yl (4a-d). The influence of $\mathrm{R}^{2}$ and $\mathrm{R}^{3}$ substituents on lipophilicity is as follows: $2 \mathrm{H}<2 \mathrm{CH}_{3}<\mathrm{H}, \mathrm{CH}_{3}<\mathrm{H}, \mathrm{C}_{2} \mathrm{H}_{5}<\mathrm{H}$, $\mathrm{C}_{6} \mathrm{H}_{5}$. Based on the above-mentioned data, it can be assumed that compounds $4 \mathbf{e}-\mathbf{l}$ are possible tautomeric isomers. This seems to be in agreement with our former findings [47]. Therefore, it can be concluded that $\log k$ values specify lipophilicity within individual series of the compounds studied more precisely than the calculated $\log P / C \log P$ data. 
Figure 2. Comparison of $\log P / C \log P$ data calculated using two programs with $\log k$ values found experimentally. (A) match of calculated data with $\log k$ values of $\mathbf{3 a}-\mathbf{o}$ found experimentally; (B) match of calculated data with $\log k$ values of $\mathbf{4 a}-\mathbf{l}$ found experimentally.

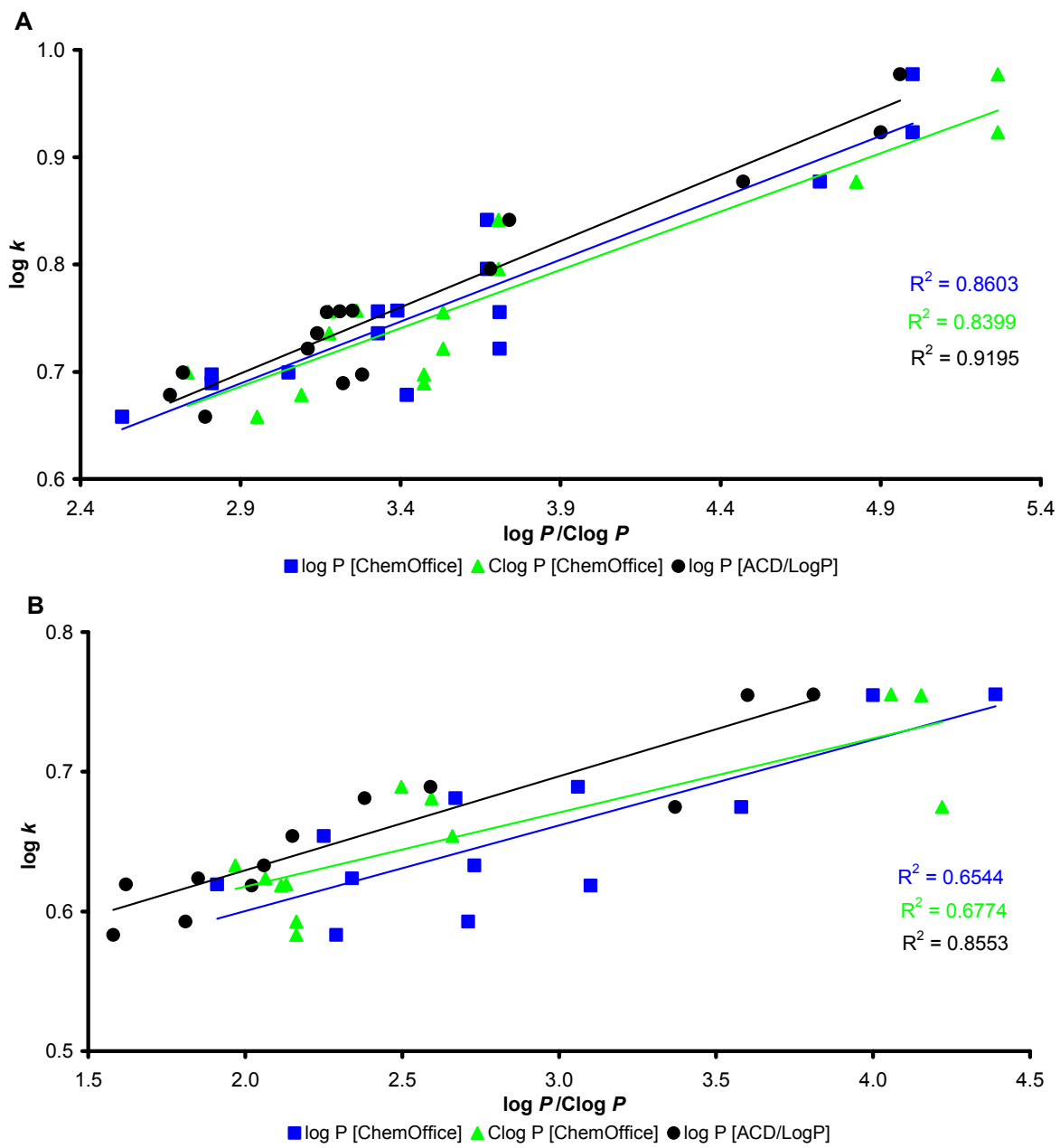

\subsection{Biological Activities}

The compounds under investigation can be divided into two groups based on their chemical structure: Group 1 included benzylidenethiosemicarbazones $\mathbf{3 a - 0}$ and Group 2 contained quinolinylvinylthiosemicarbazones $\mathbf{4 a}-\mathbf{l}$. The compounds showed a wide range of biological activities and some interesting structure-activity relationships were observed. All of the results are summarized in Table 3.

\subsubsection{Inhibition of Photosynthetic Electron Transport (PET) in Spinach Chloroplasts}

The activity of all of the evaluated derivatives related to the inhibition of photosynthetic electron transport (PET) in spinach (Spinacia oleracea L.) chloroplasts was moderate or rather low relative to the standard (see Table 3). Diuron ${ }^{\circledR}$ (DCMU), a marketed herbicide with its activity mechanism directed to photosystem II, was used as the standard. The compounds within Group 2 could not be evaluated for their structure-activity relationships because the majority of these compounds showed no PET-inhibiting activity. (E)-2-(3,4-Dichlorobenzylidene)- $N$-methylhydrazinecarbothioamide (3g) expressed the highest PET-inhibiting activity $\left(\mathrm{IC}_{50}=135.6 \mu \mathrm{mol} / \mathrm{L}\right)$ within Group 1 . 
Table 3. $\mathrm{IC}_{50}[\mu \mathrm{mol} / \mathrm{L}]$ values related to PET inhibition in spinach chloroplasts of the substituted thiosemicarbazones in comparison with 3-(3,4-dichlorophenyl)-1,1-dimethylurea (DCMU) as the standard; in vitro antifungal activity $\left(\mathrm{IC}_{80} / \mathrm{IC}_{50}[\mu \mathrm{mol} / \mathrm{L}]\right)$ of compounds compared to fluconazole (FLU) as the standard; in vitro antiproliferative activity $\mathrm{IC}_{50}$ $[\mu \mathrm{mol} / \mathrm{L}]$ of compounds compared to doxorubicin as the standard. ND $=$ not determined due to precipitation during the experiment or interaction with 2,6-dichlorophenolindophenol (DCPIP).

\begin{tabular}{|c|c|c|c|c|c|c|c|c|c|c|}
\hline \multirow{4}{*}{ Comp. } & \multirow{4}{*}{$\begin{array}{l}\text { PET } \\
\text { IC }_{50}\end{array}$} & \multicolumn{8}{|c|}{${ }^{1,2} \mathrm{MIC}\left({ }^{\mathrm{a}} \mathbf{I C}_{\mathbf{8 0}} /{ }^{\mathrm{b}} \mathbf{I C}_{\mathbf{5 0}}\right)[\boldsymbol{\mu m o l} / \mathbf{L}]$} & \multirow{4}{*}{$\begin{array}{c}\text { HCT-116 } \\
\text { IC }_{50}\end{array}$} \\
\hline & & $\mathrm{CA}^{\mathrm{a}}$ & $\mathrm{CT}^{\mathrm{a}}$ & $\mathrm{CK}^{\mathrm{a}}$ & $\mathrm{CG}^{\mathrm{a}}$ & $\mathrm{TB}^{\mathrm{a}}$ & $\mathrm{AF}^{\mathrm{b}}$ & $\mathrm{AC}^{\mathrm{b}}$ & $\mathrm{TM}^{\mathrm{b}}$ & \\
\hline & & $24 \mathrm{~h}$ & $24 \mathrm{~h}$ & $24 \mathrm{~h}$ & $24 \mathrm{~h}$ & $24 \mathrm{~h}$ & $24 \mathrm{~h}$ & $24 \mathrm{~h}$ & $72 \mathrm{~h}$ & \\
\hline & & $48 \mathrm{~h}$ & $48 \mathrm{~h}$ & $48 \mathrm{~h}$ & $48 \mathrm{~h}$ & $48 \mathrm{~h}$ & $48 \mathrm{~h}$ & $48 \mathrm{~h}$ & $120 \mathrm{~h}$ & \\
\hline 3a & ND & $>125$ & $>125$ & $>125$ & $>125$ & $>125$ & $>125$ & $>125$ & $>125$ & $41.5 \pm 1.7^{3}$ \\
\hline $3 \mathbf{b}$ & 170.1 & $>500$ & $>500$ & $>500$ & $>500$ & $>500$ & $>500$ & $>500$ & $>500$ & $>60$ \\
\hline $3 c$ & ND & $>125$ & $>125$ & $>125$ & $>125$ & $>125$ & $>125$ & $>125$ & $>125$ & - \\
\hline 3d & ND & $>500$ & $>500$ & $>500$ & $>500$ & $>500$ & $>500$ & $>500$ & $>500$ & $58.5 \pm 0.2^{3}$ \\
\hline $3 e$ & 499.3 & $>125$ & $>125$ & $>125$ & $>125$ & $>125$ & $>125$ & $>125$ & $>125$ & $>60$ \\
\hline $3 f$ & 283.3 & $>500$ & $>500$ & $>500$ & $>500$ & $>500$ & $>500$ & $>500$ & $>500$ & $46.0 \pm 0.9$ \\
\hline $3 g$ & 135.6 & $>125$ & $>125$ & $>125$ & $>125$ & $>125$ & $>125$ & $>125$ & $>125$ & $55.5 \pm 6.2$ \\
\hline \multirow{2}{*}{$3 \mathrm{~h}$} & \multirow{2}{*}{329.3} & 15.62 & 500 & 500 & 500 & 125 & $>500$ & $>500$ & 31.25 & \multirow{2}{*}{$47.0 \pm 1.3$} \\
\hline & & 31.25 & 500 & 500 & 500 & 500 & $>500$ & $>500$ & 62.50 & \\
\hline $3 \mathbf{i}$ & 280.2 & $>500$ & $>500$ & $>500$ & $>500$ & $>500$ & $>500$ & $>500$ & $>500$ & $48.5 \pm 2.8$ \\
\hline $3 \mathbf{j}$ & 425.9 & $>125$ & $>125$ & $>125$ & $>125$ & $>125$ & $>125$ & $>125$ & $>125$ & $>60$ \\
\hline \multirow{2}{*}{$3 \mathbf{k}$} & \multirow{2}{*}{586.4} & 500 & $>500$ & $>500$ & $>500$ & 500 & $>500$ & $>500$ & $>500$ & \multirow{2}{*}{$>60$} \\
\hline & & 500 & $>500$ & $>500$ & $>500$ & 500 & $>500$ & $>500$ & $>500$ & \\
\hline 31 & ND & $>500$ & $>500$ & $>500$ & $>500$ & $>500$ & $>500$ & $>500$ & $>500$ & $>60$ \\
\hline \multirow{2}{*}{$3 m$} & \multirow{2}{*}{594.6} & 62.50 & $>500$ & $>500$ & $>500$ & 15.62 & $>500$ & $>500$ & 62.50 & \multirow{2}{*}{$47.5 \pm 2.4$} \\
\hline & & 250 & $>500$ & $>500$ & $>500$ & 62.50 & $>500$ & $>500$ & 62.50 & \\
\hline $3 n$ & ND & $>500$ & $>500$ & $>500$ & $>500$ & $>500$ & $>500$ & $>500$ & $>500$ & $>60^{3}$ \\
\hline 30 & ND & $>500$ & $>500$ & $>500$ & $>500$ & $>500$ & $>500$ & $>500$ & $>500$ & $>60$ \\
\hline $4 a$ & ND & $>500$ & $>500$ & $>500$ & $>500$ & $>500$ & $>500$ & $>500$ & $>500$ & $>25$ \\
\hline \multirow{2}{*}{$4 b$} & \multirow{2}{*}{1368} & 1.95 & 1.95 & 3.90 & 1.95 & 1.95 & 3.90 & 3.90 & 3.90 & \multirow{2}{*}{$4.86 \pm 1.48^{3}$} \\
\hline & & 1.95 & 7.81 & 3.90 & 1.95 & 1.95 & 3.90 & 3.90 & 3.90 & \\
\hline $4 e$ & 302 & $>125$ & $>125$ & $>125$ & $>125$ & $>125$ & $>125$ & $>125$ & $>125$ & $1.71 \pm 0.34^{3}$ \\
\hline $4 f$ & ND & $>500$ & $>500$ & $>500$ & $>500$ & $>500$ & $>500$ & $>500$ & $>500$ & - \\
\hline \multirow{2}{*}{$4 h$} & \multirow{2}{*}{ ND } & $>125$ & $>125$ & $>125$ & $>125$ & $>125$ & $>125$ & $>125$ & $>125$ & \multirow{2}{*}{$24.97 \pm 4.29^{3}$} \\
\hline & & $>125$ & $>125$ & $>125$ & $>125$ & $>125$ & $>125$ & $>125$ & $>125$ & \\
\hline \multirow{2}{*}{$4 i$} & \multirow{2}{*}{ ND } & $>500$ & $>500$ & $>500$ & $>500$ & $>500$ & $>500$ & $>500$ & $>500$ & \multirow{2}{*}{$>25^{3}$} \\
\hline & & $>500$ & $>500$ & $>500$ & $>500$ & $>500$ & $>500$ & $>500$ & $>500$ & \\
\hline \multirow{2}{*}{$4 j$} & \multirow{2}{*}{520.4} & 125 & $>250$ & $>250$ & 125 & 125 & $>250$ & $>250$ & 125 & \multirow{2}{*}{$20.75 \pm 5.34^{3}$} \\
\hline & & $>250$ & $>250$ & $>250$ & 125 & $>250$ & $>250$ & $>250$ & 125 & \\
\hline $4 \mathbf{k}$ & ND & $>500$ & $>500$ & $>500$ & 62.50 & $>500$ & $>500$ & $>500$ & 62.50 & \\
\hline$+\mathbf{H}$ & IVD & $>500$ & $>500$ & $>500$ & 500 & $>500$ & $>500$ & $>500$ & 62.50 & \\
\hline 41 & ND & 31.25 & 125 & 31.25 & 15.62 & 15.62 & 125 & 15.62 & 15.62 & $16.28 \pm 1.69^{3}$ \\
\hline & & 62.50 & 125 & 125 & 31.25 & 125 & 125 & 62.50 & 15.62 & \\
\hline
\end{tabular}


Table 3. Cont.

\begin{tabular}{|c|c|c|c|c|c|c|c|c|c|c|}
\hline \multirow{4}{*}{ Comp. } & \multirow{4}{*}{$\begin{array}{l}\text { PET } \\
\text { IC }_{50}\end{array}$} & \multicolumn{8}{|c|}{${ }^{1,2} \mathrm{MIC}\left({ }^{\mathrm{a}} \mathbf{I C}_{\mathbf{8 0}} /{ }^{\mathrm{b}} \mathbf{I C}_{\mathbf{5 0}}\right)[\boldsymbol{\mu m o l} / \mathbf{L}]$} & \multirow{4}{*}{$\begin{array}{c}\text { HCT-116 } \\
\text { IC }_{50}\end{array}$} \\
\hline & & $\mathrm{CA}^{\mathrm{a}}$ & $\mathrm{CT}^{\mathrm{a}}$ & $\mathrm{CK}^{\mathrm{a}}$ & $\mathrm{CG}^{\mathrm{a}}$ & $\mathrm{TB}^{\mathrm{a}}$ & $\mathrm{AF}^{\mathrm{b}}$ & $\mathrm{AC}^{\mathrm{b}}$ & $\mathrm{TM}^{\mathrm{b}}$ & \\
\hline & & $24 \mathrm{~h}$ & $24 \mathrm{~h}$ & $24 \mathrm{~h}$ & $24 \mathrm{~h}$ & $24 \mathrm{~h}$ & $24 \mathrm{~h}$ & $24 \mathrm{~h}$ & $72 \mathrm{~h}$ & \\
\hline & & $48 \mathrm{~h}$ & $48 \mathrm{~h}$ & $48 \mathrm{~h}$ & $48 \mathrm{~h}$ & $48 \mathrm{~h}$ & $48 \mathrm{~h}$ & $48 \mathrm{~h}$ & $120 \mathrm{~h}$ & \\
\hline DCMU & 1.9 & - & - & - & - & - & - & & - & - \\
\hline \multirow{2}{*}{ FLU } & \multirow{2}{*}{-} & 0.06 & 0.12 & 3.91 & 0.98 & 0.24 & $>125$ & $>125$ & 1.95 & \multirow{2}{*}{ - } \\
\hline & & 0.12 & $>125$ & 15.62 & 3.91 & 0.48 & $>125$ & $>125$ & 3.91 & \\
\hline DXR & - & - & - & - & - & - & - & - & - & $10 \pm 1.1$ \\
\hline
\end{tabular}

${ }^{1}$ The MIC determination was performed according to the CLSI reference protocol: ${ }^{\text {a }}$ M27-A2 for yeasts $\left(\mathrm{IC}_{80}\right.$ value) and ${ }^{\mathrm{b}} \mathrm{M} 38$-A for moulds $\left(\mathrm{IC}_{50}\right.$ value); $\mathrm{CA}=$ Candida albicans, $\mathrm{CT}=$ Candida tropicalis, $\mathrm{CK}=$ Candida krusei, $\mathrm{CG}=$ Candida glabrata, $\mathrm{TB}=$ Trichosporon beigelii, $\mathrm{AF}=$ Aspergillus fumigatus, $\mathrm{AC}=$ Absidia corymbifera, and $\mathrm{TM}=$ Trichophyton mentagrophytes. ${ }^{2}$ All compounds were tested for short and long term activity. When inactive only one value is presented. ${ }^{3}$ Synthesis and anticancer activity described elsewhere [34,44]. HCT-116 human colon cancer cells, DXR- doxorubicin as the standard.

Figure 3 illustrates the dependence of the PET-inhibiting activity, expressed by the negative logarithm of the $\log \left(1 / \mathrm{IC}_{50}[\mathrm{~mol} / \mathrm{L}]\right)$ value on the lipophilicity, expressed as $\log k$, of benzylidenethiosemicarbazones 3a-o. Although the dependence seems to be clear, it is not possible to draw a simple relationship. The regression with parabolic function did not provide a good correlation. This suggests that lipophilicity is only one of the important factors. Nevertheless, despite the relatively low inhibitory activity of the compounds studied, the correlations between $\log \left(1 / \mathrm{IC}_{50}\right)$ and the lipophilicity showed a bilinear course: in the range of $\log k=0.6580$ (3k) to $\log k=0.7563$ (3g) PET-inhibiting activity linearly increased with increasing compound lipophilicity; however, with a further increase in lipophilicity, the inhibitory activity declined. Generally, 4-Br-benzylidenethiosemicarbazones 3k-0 showed the worst PET inhibition. Disubstitution by 3,4-Cl of the benzylidene ring seems to be more advantageous than disubstitution by $2,3-\mathrm{Cl}$ of the benzylidene moiety. It can be stated that within the 3,4-Cl-benzylidenethiosemicarbazones $3 \mathbf{f}-\mathbf{j} N, N$-disubstitution caused a decrease in PET inhibition (compare $\mathbf{3 g} / \mathbf{3 h}$ ). Based on these facts, it can be concluded that PET-inhibiting activity would probably be negatively influenced by bulky or long-chain alkyls or by the substitution of the second hydrogen of the terminal amino moiety.

\subsubsection{In Vitro Antifungal Susceptibility Testing}

The antifungal activity of the compounds studied was tested against several pathogenic fungi and the results of the screening are shown in Table 3. The values are correlated to the standard drug fluconazole. The majority of the compounds studied appeared to be inactive against the fungal strains tested. Nevertheless, some of them, $\mathbf{3 h}, \mathbf{3 m}$, and $\mathbf{4}$, showed moderate activity, especially against Candida albicans, Trichosporon beigelii, and Trichophyton mentagrophytes. (E)-2-(Quinolin-2ylvinyl)- $N, N$-dimethylhydrazinecarbothioamide (4b) expressed the strongest activity among all of the compounds tested. Compound $\mathbf{4 b}$ was more active than fluconazole against Aspergillus fumigatus and Absidia corymbifera. Furthermore, this compound showed an interesting pattern of long terminal 
activity and was active at a comparable level for $24 \mathrm{~h}$ and $48 \mathrm{~h}$ protocols. The (Candida tropicalis and Candida krusei) activity of fluconazole decreased significantly for some fungi.

Figure 3. Relationships between PET inhibition $\log \left(1 / \mathrm{IC}_{50}\right)[\mathrm{mol} / \mathrm{L}]$ in spinach chloroplasts and lipophilicity of studied benzylidenethiosemicarbazones $\mathbf{3 a}-\mathbf{o}$.

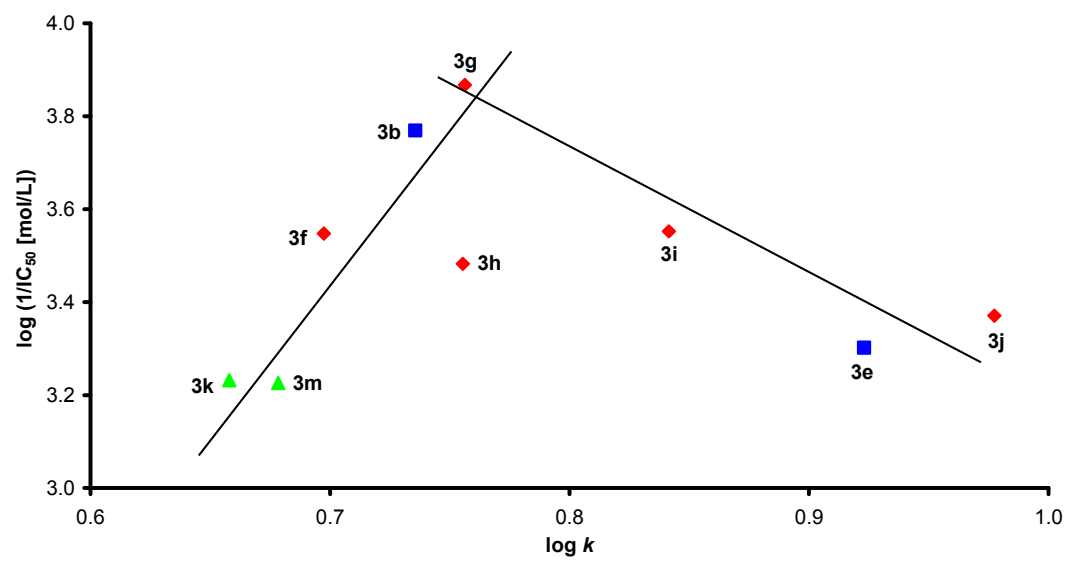

As most compounds showed only a moderate or no activity, no thorough structure-activity relationships could be established. According to the results presented in Table 3, it can be concluded that compounds with a quinoline nucleus, i.e., quinolinylvinylthiosemicarbazones (Group 2) seem to be more effective antifungals than Group 1, i.e., benzylidenethiosemicarbazones. Based on recent results [32], it was expected that 8-hydroxyquinolinylvinylthiosemicarbazones would possess a higher antifungal activity than antifungal tests showed. It can be stated, contrary to PET-inhibiting activity, that $\mathrm{N}, \mathrm{N}$-disubstitution of the terminal amino moiety by two methyl groups is crucial for a high antifungal effect. This fact corresponds to results obtained by Opletalova et al. [26].

\subsubsection{In Vitro Antiproliferative Activity}

The antiproliferative activity of all of the compounds was examined against the human colon cancer (HCT-116) cell line using an MTS assay. The HCT-116 p53 wild type cell line was chosen on the basis of our former experience and some results on the activity of quinoline-based thiosemicarbazones that was published recently. Namely, compounds $\mathbf{4 a - 1}$ have been tested previously for their wideranging anticancer activity [34]. The antiproliferative activity of the compounds evaluated was assessed using Doxorubicin as a reference compound. In general, quinoline-based thiosemicarbazones 4 seem to have a much better anticancer activity than halogenophenyl compounds 3 . Thus, the quinoline nucleus can be defined as being crucial for antiproliferative activity. A more detailed analysis of the anticancer activity of quinoline-based thiosemicarbazone is available [34]. Benzylidenethiosemicarbazones were much less active against the cells tested. Compound 3a appeared to be the most active in this assay. Nevertheless, some more general conclusions can be drawn from the gathered data. Dichlorosubstituted compounds are in general more active than monobromo equivalents. The free amino group or substitution pattern with small substituents such as methyl or ethyl are favorable for activity. According to our former results the chelating ability of the compounds may be one of the prerequisites of the antiproliferative activity. In this study we have measured the UV-VIS spectra of the compounds in presence of various concentration of $\mathrm{Fe}^{3+}$ cations to observe its 
chelating potency (supplementary material). Isosbestic points are observable in case of more active compounds like $\mathbf{4 a}-\mathbf{l}$ series while in $\mathbf{3 a}-\mathbf{o}$ only minor or no interaction between ligand and metal can be noticed. Compound $\mathbf{4 b}$ one of the most active against HCT-116 cells and in antifungal assays gave clear isosbestic points at $375 \mathrm{~nm}$. However as $\mathbf{4 j}$ give also two points at 330 and $385 \mathrm{~nm}$, iron chelating ability should be regarded only as one of the factor influencing the biological activity.

\section{Experimental}

\subsection{General}

All reagents were purchased from Sigma-Aldrich (St. Louis, MO, USA) or Princeton Chemicals Ltd. (Luton, Bedfordshire, UK). Kieselgel 60, 0.040-0.063 mm (Merck, Darmstadt, Germany) was used for the column chromatography. Syntheses were performed in a CEM DISCOVERY microwave reactor (Matthews, NC, USA) with temperature and pressure control. TLC experiments were performed on alumina-backed silica gel $40 \mathrm{~F}_{254}$ plates (Merck, Darmstadt, Germany). The plates were illuminated under UV $(254 \mathrm{~nm})$ and evaluated in an iodine vapor. The melting points were determined on an Optimelt MPA100 instrument (SRS, USA) and are uncorrected. Infrared (IR) spectra were recorded on a Smart MIRacle ${ }^{\mathrm{TM}}$ ATR ZnSe for Nicolet ${ }^{\mathrm{TM}}$ Impact 410 FT-IR spectrometer (Thermo Fisher Scientific, Waltham, MA, USA). The spectra were obtained by the accumulation of 256 scans with $2 \mathrm{~cm}^{-1}$ resolution in the region of $4000-600 \mathrm{~cm}^{-1}$. All ${ }^{1} \mathrm{H}$ and ${ }^{13} \mathrm{C}-\mathrm{NMR}$ spectra were recorded on a Bruker Avance III $400 \mathrm{MHz}$ FT-NMR spectrometer $\left(400 \mathrm{MHz}\right.$ for ${ }^{1} \mathrm{H}$ and $100 \mathrm{MHz}$ for ${ }^{13} \mathrm{C}$, BrukerBioSpin Comp., Karlsruhe, Germany). Chemicals shifts are reported in ppm $(\delta)$ using internal $\mathrm{Si}\left(\mathrm{CH}_{3}\right)_{4}$ as the reference with diffuse, easily exchangeable signals being omitted. HR-MS (EI) analysis was performed on a Finnigan MAT95 spectrometer (ThermoFinnigan, San Jose, CA, USA) for all new compounds.

\subsection{Synthesis}

\subsubsection{General Procedure for Synthesis of Thiosemicarbazones 3a-o}

Equimolar quantities of an appropriate thiosemicarbazide and benzaldehyde derivative were mixed and 2 drops of glacial acetic acid were added. The resulting mixture was heated in a microwave reactor at $85{ }^{\circ} \mathrm{C}$ for $12 \mathrm{~min}$ ( $\max$ microwave power $75 \mathrm{~W}$ ). After cooling, the precipitated solids were filtered off, washed with ether and crystallized from methanol. The compounds $\mathbf{3 a}-\mathbf{o}$ studied are presented in Table 1.

(E)-2-(2,3-Dichlorobenzylidene)hydrazinecarbothioamide (3a). Yield: 78\%, ${ }^{1} \mathrm{H}-\mathrm{NMR}$ ( $d_{6}$-DMSO, $400 \mathrm{MHz}, \mathrm{ppm}): 11.69$ (bs, 1H, NH), 8.49 (s, 1H, CH), 8.36 (s, 1H, NH), 8.30 (d, J=8.0 Hz, 1H, $\mathrm{ArH}), 8.18$ (bs, 1H, NH), 7.66 (d, $J=7.9 \mathrm{~Hz}, 1 \mathrm{H}, \mathrm{ArH}), 7.38(\mathrm{t}, J=8.0 \mathrm{~Hz}, 1 \mathrm{H}, \mathrm{ArH}) .{ }^{13} \mathrm{C}-\mathrm{NMR}$ (d $d_{6}$-DMSO, $100 \mathrm{MHz}, \mathrm{ppm}$ ): 178.8, 138.2, 134.2; 132.6, 131.6, 131.2, 128.5, 126.5. MP: $226-227{ }^{\circ} \mathrm{C}$ HR-MS (EI): 246.9745 (calc. for $\mathrm{C}_{8} \mathrm{H}_{7} \mathrm{Cl}_{2} \mathrm{~N}_{3} \mathrm{~S}: 246.9738$ ).

(E)-2-(2,3-Dichlorobenzylidene)-N-methylhydrazinecarbothioamide (3b). Yield: $74 \%,{ }^{1} \mathrm{H}-\mathrm{NMR}$ $\left(d_{6}\right.$-DMSO, $\left.400 \mathrm{MHz}, \mathrm{ppm}\right): 11.76(\mathrm{~s}, 1 \mathrm{H}, \mathrm{NH}), 8.68(\mathrm{~d}, J=4.4 \mathrm{~Hz}, 1 \mathrm{H}, \mathrm{NH}), 8.49$ (s, $\left.1 \mathrm{H}, \mathrm{CH}\right), 8.29$ 
$(\mathrm{d}, J=8.0 \mathrm{~Hz}, 1 \mathrm{H}, \operatorname{ArH}), 7.67(\mathrm{~d}, J=7.9 \mathrm{~Hz}, 1 \mathrm{H}, \operatorname{ArH}), 7.41(\mathrm{t}, J=7.9 \mathrm{~Hz}, 1 \mathrm{H}, \operatorname{ArH}), 3.02(\mathrm{~d}, J=4.5 \mathrm{~Hz}$, $\left.\mathrm{CH}_{3}\right) .{ }^{13} \mathrm{C}-\mathrm{NMR}\left(d_{6}\right.$-DMSO, $\left.100 \mathrm{MHz}, \mathrm{ppm}\right): 178.5,137.7,134.5,132.5,131.4,131.3,128.4,126.2$, 31.4. MP: $223-224^{\circ} \mathrm{C}$, HR-MS (EI): 260.9891 (calc. for $\mathrm{C}_{9} \mathrm{H}_{9} \mathrm{Cl}_{2} \mathrm{~N}_{3} \mathrm{~S}: 260.9894$ ).

(E)-2-(2,3-Dichlorobenzylidene)-N,N-dimethylhydrazinecarbothioamide (3c). Yield: 69\%, ${ }^{1} \mathrm{H}-\mathrm{NMR}$ ( $d_{6}$-DMSO, $\left.400 \mathrm{MHz}, \mathrm{ppm}\right): 11.27(\mathrm{~s}, 1 \mathrm{H}, \mathrm{NH}), 8.64(\mathrm{~s}, 1 \mathrm{H}, \mathrm{CH}), 7.92$ (dd, $J_{1}=7.9 \mathrm{~Hz}, J_{2}=1.4 \mathrm{~Hz}$, $1 \mathrm{H}, \mathrm{ArH}), 7.66\left(\mathrm{dd}, J_{1}=7.9 \mathrm{~Hz}, J_{2}=1.5 \mathrm{~Hz}, 1 \mathrm{H}, \mathrm{ArH}\right), 7,42(\mathrm{t}, J=8.0 \mathrm{~Hz}, 1 \mathrm{H}, \mathrm{ArH}), 3.31(\mathrm{~s}, 6 \mathrm{H}$, $\left.\mathrm{CH}_{3}\right) .{ }^{13} \mathrm{C}-\mathrm{NMR}\left(d_{6}\right.$-DMSO, $\left.100 \mathrm{MHz}, \mathrm{ppm}\right): 180.8,140.0,134.7,132.7,131.5,131.0,128.8,125.7$, 42.4. MP: $145-146^{\circ} \mathrm{C}$, HR-MS (EI): 275.0047 (calc. for $\mathrm{C}_{10} \mathrm{H}_{11} \mathrm{Cl}_{2} \mathrm{~N}_{3} \mathrm{~S}: 275.0051$ ).

(E)-2-(2,3-Dichlorobenzylidene)-N-ethylhydrazinecarbothioamide (3b). Synthesis and more detailed analysis of the structure is available [44]. Yield: 67\%, ${ }^{1} \mathrm{H}-\mathrm{NMR}\left(d_{6}\right.$-DMSO, $\left.400 \mathrm{MHz}, \mathrm{ppm}\right): 11.70$ (s, $1 \mathrm{H}, \mathrm{NH}), 8.70(\mathrm{~m}, 1 \mathrm{H}, \mathrm{NH}), 8.49(\mathrm{~s}, 1 \mathrm{H}, \mathrm{CH}), 8.31(\mathrm{~d}, J=7.9 \mathrm{~Hz}, 1 \mathrm{H}, \mathrm{ArH}), 7.67(\mathrm{~d}, J=7.9 \mathrm{~Hz}, 1 \mathrm{H}$, $\mathrm{ArH}), 7.41(\mathrm{t}, J=7.9 \mathrm{~Hz}, 1 \mathrm{H}, \mathrm{ArH}), 3.70-3.52\left(\mathrm{~m}, 2 \mathrm{H}, \mathrm{CH}_{2}\right), 1.16\left(\mathrm{t}, J=7.0 \mathrm{~Hz}, 3 \mathrm{H}, \mathrm{CH}_{3}\right) .{ }^{13} \mathrm{C}-\mathrm{NMR}$ (d6-DMSO, $100 \mathrm{MHz}, \mathrm{ppm}): 177.4,137.6,134.4,132.5,131.5,131.3,128.5,126.02,38.9$, 14.7. MP: 213-214 ${ }^{\circ} \mathrm{C}$ HR-MS (EI): 275.0054 (calc. for $\left.\mathrm{C}_{10} \mathrm{H}_{11} \mathrm{Cl}_{2} \mathrm{~N}_{3} \mathrm{~S}: 275.0051\right)$, IR: $3349\left(v_{\mathrm{NH}}\right), 3142\left(v_{\mathrm{PhH}}\right)$, $2983\left(v_{\mathrm{CH}}\right), 1584\left(v_{\mathrm{C}=\mathrm{N}}\right), 1542\left(v_{\mathrm{C}-\mathrm{N}}\right), 1520\left(v_{\mathrm{CH}}\right), 1452\left(v_{\mathrm{CH} / \mathrm{NH}}\right), 1416\left(v_{\mathrm{CH} 3}\right), 1311\left(v_{\mathrm{CNH}}\right), 1264$ $\left(v_{\mathrm{N}-\mathrm{C}} / \delta_{\mathrm{NH}}\right), 1160\left(v_{\mathrm{N}-\mathrm{N}}\right), 1108\left(\omega_{\mathrm{NH}}\right), 1042\left(\rho_{\mathrm{NH}}\right), 929,906\left(\delta_{\mathrm{NCS}}\right), 782\left(v_{\mathrm{CS}}\right), 737,704(\operatorname{ring}), 626\left(\delta_{\mathrm{N}-\mathrm{C}-\mathrm{N}}\right)$. UV-VIS (methanol; loge): 323.0 (3.96), 237.0 (3.67), 204.0 (3.91).

(E)-2-(2,3-dichlorobenzylidene)-N-phenylhydrazinecarbothioamide (3b). Yield: $\quad 79 \%,{ }^{1} \mathrm{H}-\mathrm{NMR}$ (d $d_{6}$-DMSO, $\left.400 \mathrm{MHz}, \mathrm{ppm}\right): 12.08$ (bs, 1H, NH), $10.26(\mathrm{~s}, 1 \mathrm{H}, \mathrm{NH}), 8.62(\mathrm{~s}, 1 \mathrm{H}, \mathrm{CH}), 8.47(\mathrm{~d}$, $J=9.3 \mathrm{~Hz}, 1 \mathrm{H}, \operatorname{ArH}), 7.68(\mathrm{t}, J=7.1 \mathrm{~Hz}, 1 \mathrm{H}, \mathrm{ArH}), 7.55(\mathrm{~d}, J=7.7 \mathrm{~Hz}, 2 \mathrm{H}, \operatorname{ArH}), 7.43-7.37$ (m, 3H, $\mathrm{ArH}), 7.23$ (t, $J=7.6 \mathrm{~Hz}, 1 \mathrm{H}, \mathrm{ArH}) .{ }^{13} \mathrm{C}-\mathrm{NMR}$ ( $d_{6}$-DMSO, $\left.100 \mathrm{MHz}, \mathrm{ppm}\right): 176.9,139.5,138.9$, 134.3, 132.6, 131.8, 131.5, 128.6, 126.8, 126.6, 126.0. MP: 203-204 ${ }^{\circ} \mathrm{C}$, HR-MS (EI): 323.0066 (calc. for $\mathrm{C}_{14} \mathrm{H}_{11} \mathrm{Cl}_{2} \mathrm{~N}_{3} \mathrm{~S}: 323.0051$ ).

(E)-2-(3,4-Dichlorobenzylidene)hydrazinecarbothioamide (3f). Synthesis and more detailed analysis of the structure is available [44]. Yield: $85 \%,{ }^{1} \mathrm{H}-\mathrm{NMR}\left(d_{6}\right.$-DMSO, $\left.400 \mathrm{MHz}, \mathrm{ppm}\right): 11.56(\mathrm{~s}, 1 \mathrm{H}$, $\mathrm{NH}), 8.28(\mathrm{~s}, 1 \mathrm{H}, \mathrm{NH}), 8.24(\mathrm{~d}, J=1.7 \mathrm{~Hz}, 1 \mathrm{H}, \mathrm{ArH}), 8.00(\mathrm{~s}, 1 \mathrm{H}, \mathrm{CH}), 7.72(\mathrm{dd}, J=8.4,1.8 \mathrm{~Hz}, 1 \mathrm{H}$, $\mathrm{ArH}), 7.64(\mathrm{~d}, J=8.3 \mathrm{~Hz}, 1 \mathrm{H}, \mathrm{ArH}) .{ }^{13} \mathrm{C}-\mathrm{NMR}\left(d_{6}\right.$-DMSO, $\left.100 \mathrm{MHz}, \mathrm{ppm}\right): 178.7,139.9,135.6$, 132.3, 132.3, 131.2, 128.7, 128.2. MP: 205-206 ${ }^{\circ} \mathrm{C}$ [34]. IR: 3395, $3256\left(v_{\mathrm{NH}}\right), 3154\left(v_{\mathrm{PhH}}\right), 2992$ $\left(v_{\mathrm{CH}}\right), 1596\left(\delta_{\mathrm{NH} 2}\right), 1538\left(v_{\mathrm{C}=\mathrm{N}}\right), 1471\left(\delta_{\mathrm{CH} / \mathrm{NH}}\right), 1291\left(v_{\mathrm{N}-\mathrm{X}} / \delta_{\mathrm{NH}}\right), 1129\left(v_{\mathrm{N}-\mathrm{N}}\right), 1100\left(\omega_{\mathrm{NH}}\right), 1065\left(\rho_{\mathrm{NH}}\right)$, 1031 $\left(v_{\text {ring }}\right), 938\left(\delta_{\mathrm{CH}}\right), 870,823\left(v_{\mathrm{CS}}\right), 625\left(\delta_{\mathrm{N}-\mathrm{C}-\mathrm{N}}\right)$. UV-VIS $(\mathrm{MeOH} ; \log \varepsilon)$ : $320.0(4.01), 239.0$ (3.63), $203.0(3.92)$.

(E)-2-(3,4-Dichlorobenzylidene)-N-methylhydrazinecarbothioamide $\quad$ (3f). Yield: $\quad 89 \% \quad{ }^{1} \mathrm{H}-\mathrm{NMR}$ (d $d_{6}$-DMSO, $\left.400 \mathrm{MHz}, \mathrm{ppm}\right): 11.63(\mathrm{~s}, 1 \mathrm{H}, \mathrm{NH}), 8.68$ (d, $\left.J=3.8 \mathrm{~Hz}, 1 \mathrm{H}, \mathrm{NH}\right), 8.20(\mathrm{~s}, 1 \mathrm{H}, \mathrm{CH}), 8.00$ $(\mathrm{s}, 1 \mathrm{H}, \mathrm{ArH}), 7.69$ (dd, $\left.J_{l}=23.9, J_{2}=8.3 \mathrm{~Hz}, 2 \mathrm{H}\right), 3.03(\mathrm{~d}, J=4.3 \mathrm{~Hz}, 3 \mathrm{H}) .{ }^{13} \mathrm{C}-\mathrm{NMR}\left(d_{6}\right.$-DMSO, 100 $\mathrm{MHz}, \mathrm{ppm})$ : $178.4,139.4,135.7,132.2,132.2,131.2,128.5,128.1,31.62 . \mathrm{MP}: 202-203{ }^{\circ} \mathrm{C}$. HR-MS (EI): 260.9902 (calc. for $\mathrm{C}_{9} \mathrm{H}_{9} \mathrm{Cl}_{2} \mathrm{~N}_{3} \mathrm{~S}: 260.9894$ ). 
(E)-2-(3,4-Dichlorobenzylidene)-N,N-dimethylhydrazinecarbothioamide (3h). Yield: $79 \%{ }^{1} \mathrm{H}-\mathrm{NMR}$ (d $d_{6}$-DMSO, $\left.400 \mathrm{MHz}, \mathrm{ppm}\right): 11.12(\mathrm{~s}, 1 \mathrm{H}, \mathrm{NH}), 8.17(\mathrm{~s}, 1 \mathrm{H}, \mathrm{CH}), 7.86(\mathrm{~d}, J=1.7 \mathrm{~Hz}, 1 \mathrm{H}, \mathrm{ArH})$, 7.70-7.63 (m, 1H, ArH), $3.30\left(\mathrm{~s}, 6 \mathrm{H}, \mathrm{CH}_{3}\right) .{ }^{13} \mathrm{C}-\mathrm{NMR}\left(d_{6}-\mathrm{DMSO}, 100 \mathrm{MHz}, \mathrm{ppm}\right): 181.0,141.5$, 136.0, 132.1, 132.0, 131.5, 128.4, 127.0, 42.5. MP: 138-139 ${ }^{\circ} \mathrm{C}$ HR-MS (EI): 275.0048 (calc. for $\left.\mathrm{C}_{10} \mathrm{H}_{11} \mathrm{Cl}_{2} \mathrm{~N}_{3} \mathrm{~S}: 275.0051\right)$.

(E)-2-(3,4-Dichlorobenzylidene)-N-ethylhydrazinecarbothioamide $\quad$ (3i). $\quad$ Yield: $\quad 83 \%, \quad{ }^{1} \mathrm{H}-\mathrm{NMR}$ ( $d_{6}$-DMSO, $\left.400 \mathrm{MHz}, \mathrm{ppm}\right): 11.56(\mathrm{~s}, 1 \mathrm{H}, \mathrm{NH}), 8.73(\mathrm{t}, J=5.7 \mathrm{~Hz}, 1 \mathrm{H}, \mathrm{NH}), 8.19$ (d, $J=1.7 \mathrm{~Hz}, 1 \mathrm{H}$, ArH), $8.00(\mathrm{~s}, 1 \mathrm{H}, \mathrm{CH}), 7.78-7.70(\mathrm{~m}, 1 \mathrm{H}, \mathrm{ArH}), 7.67$ (d, $J=8.3 \mathrm{~Hz}, 1 \mathrm{H}), 3.61\left(\mathrm{~m}, 2 \mathrm{H}, \mathrm{CH}_{2}\right), 1.16$ $\left(\mathrm{t}, J=7.1 \mathrm{~Hz}, 3 \mathrm{H}, \mathrm{CH}_{3}\right) .{ }^{13} \mathrm{C}-\mathrm{NMR}\left(d_{6}\right.$-DMSO, $\left.100 \mathrm{MHz}, \mathrm{ppm}\right): 177.3,139.5,135.6,132.2,132.2,131.3$, 128.6, 128.1, 38.8, 15.0. MP: $177-178{ }^{\circ} \mathrm{C}$, HR-MS (EI): 275.0058 (calc. for $\mathrm{C}_{10} \mathrm{H}_{11} \mathrm{Cl}_{2} \mathrm{~N}_{3} \mathrm{~S}: 275.0051$ ).

(E)-2-(3,4-Dichlorobenzylidene)-N-phenylhydrazinecarbothioamide $\quad(\mathbf{3 j}) . \quad$ Yield: $\quad 86 \%,{ }^{1} \mathrm{H}-\mathrm{NMR}$ (d $d_{6}$-DMSO, $\left.400 \mathrm{MHz}, \mathrm{ppm}\right): 11.96(\mathrm{~s}, 1 \mathrm{H}, \mathrm{NH}), 10.27$ (s, 1H, NH), 8.35 (s, 1H, NH), 8.12 (s, 1H, Ar), $7.82(\mathrm{dd}, J=8.4,1.7 \mathrm{~Hz}, 1 \mathrm{H}, \mathrm{ArH}), 7.68$ (d, $J=8.3 \mathrm{~Hz}, 1 \mathrm{H}, \mathrm{ArH}), 7.53$ (d, $J=7.7 \mathrm{~Hz}, 2 \mathrm{H}, \mathrm{Ph}), 7.39$ (t $J=7.8 \mathrm{~Hz}, 2 \mathrm{H}, \mathrm{Ph}), 7.24(\mathrm{t}, J=7.4 \mathrm{~Hz}, 1 \mathrm{H}, \mathrm{Ph}) .{ }^{13} \mathrm{C}-\mathrm{NMR}\left(d_{6}\right.$-DMSO, $\left.100 \mathrm{MHz}, \mathrm{ppm}\right): 176.9$, 140.6, 139.5, 135.4, 132.5, 132.3, 131.2, 128.9, 128.6, 126.9, 126.1. MP: 200-201 ${ }^{\circ} \mathrm{C}[28]$.

(E)-2-(4-Bromobenzylidene)hydrazinecarbothioamide (3k). Yield: $69 \%{ }^{1} \mathrm{H}-\mathrm{NMR} \quad\left(d_{6}\right.$-DMSO, $400 \mathrm{MHz}, \mathrm{ppm}): 11.48$ (s, 1H, NH), 8.23 (s, 1H, NH), 8.07 (s, 1H, NH), 8.02 (s, 1H, CH), 7.77 (d, $J=8.5 \mathrm{~Hz}, 2 \mathrm{H}, \mathrm{ArH}), 7.59$ (d, $J=8.5 \mathrm{~Hz}, 2 \mathrm{H}, \mathrm{ArH}) .{ }^{13} \mathrm{C}-\mathrm{NMR}\left(d_{6}\right.$-DMSO, $\left.100 \mathrm{MHz}, \mathrm{ppm}\right): 178.6$, 141.4, 134.0, 132.1, 129.6, 123.5. MP: $222^{\circ} \mathrm{C}[48]$.

(E)-2-(4-bromobenzylidene)-N-methylhydrazinecarbothioamide (3I). Yield: $72 \%$; ${ }^{1} \mathrm{H}-\mathrm{NMR} \quad\left(d_{6^{-}}\right.$ DMSO, $400 \mathrm{MHz}, \mathrm{ppm}): 11.54(\mathrm{~s}, 1 \mathrm{H}, \mathrm{NH}), 8.57(\mathrm{~d}, J=4.0 \mathrm{~Hz}, 1 \mathrm{H}), 8.01$ (s, 1H, CH), 7.77 (d, $J=8.3 \mathrm{~Hz}, 2 \mathrm{H}, \mathrm{ArH}), 7.61$ (d, $J=8.4 \mathrm{~Hz}, 2 \mathrm{H}, \mathrm{ArH}), 3.02\left(\mathrm{~d}, J=4.4 \mathrm{~Hz}, 3 \mathrm{H}, \mathrm{CH}_{3}\right) .{ }^{13} \mathrm{C}-\mathrm{NMR}$ (d $d_{6}$-DMSO, $\left.100 \mathrm{MHz}, \mathrm{ppm}\right):$ 178.3, 140.8, 134.1, 132.0, 129.4, 123.4, 31.2. MP: 204-205 ${ }^{\circ} \mathrm{C}$ [49].

(E)-2-(4-bromobenzylidene)-N,N-dimethylhydrazinecarbothioamide (3m). Yield: $61 \%,{ }^{1} \mathrm{H}-\mathrm{NMR}$ (d $d_{6}$-DMSO, $\left.400 \mathrm{MHz}, \mathrm{ppm}\right): 11.00(\mathrm{~s}, 1 \mathrm{H}, \mathrm{NH}), 8.17(\mathrm{~s}, 1 \mathrm{H}, \mathrm{CH}), 7.71-7.45(\mathrm{~m}, 4 \mathrm{H}, \mathrm{ArH}), 3.29$ $\left(\mathrm{s}, 6 \mathrm{H}, \mathrm{CH}_{3}\right) .{ }^{13} \mathrm{C}-\mathrm{NMR}\left(d_{6}\right.$-DMSO, $\left.100 \mathrm{MHz}, \mathrm{ppm}\right): 181.0,143.0,134.4,132.2,129.0,123.1,42.6$. MP: $150-151^{\circ} \mathrm{C}[50]$.

(E)-2-(4-Bromobenzylidene)-N-ethylhydrazinecarbothioamide (3n). Synthesis and more detailed analysis of the structure is available [44]. Yield: $78 \%,{ }^{1} \mathrm{H}-\mathrm{NMR}\left(d_{6}\right.$-DMSO, $\left.400 \mathrm{MHz}, \mathrm{ppm}\right): 11.47$ $(\mathrm{s}, 1 \mathrm{H}, \mathrm{NH}), 8.61(\mathrm{t}, J=5.8 \mathrm{~Hz}, 1 \mathrm{H}, \mathrm{NH}), 8.02(\mathrm{~s}, 1 \mathrm{H}, \mathrm{CH}), 7.77(\mathrm{~d}, J=8.5 \mathrm{~Hz}, 2 \mathrm{H}, \mathrm{ArH}), 7.61$ (d, $J=8.5 \mathrm{~Hz}, 2 \mathrm{H}, \operatorname{ArH}), 3.63-3.56\left(\mathrm{~m}, J=7.0 \mathrm{~Hz}, 2 \mathrm{H}, \mathrm{CH}_{2}\right), 1.15(\mathrm{t}, J=7.1 \mathrm{~Hz}, 3 \mathrm{H}, \operatorname{ArH})$. ${ }^{13} \mathrm{C}-\mathrm{NMR}\left(d_{6}\right.$-DMSO, $\left.100 \mathrm{MHz}, \mathrm{ppm}\right): 177.2,140.9,134.1,132.0,129.6,123.4,38.8,15.0 . \mathrm{MP}:$ 199-200 ${ }^{\circ} \mathrm{C}$, HR-MS(EI): 284.9944 (calc. for $\mathrm{C}_{10} \mathrm{H}_{12} \mathrm{BrN}_{3} \mathrm{~S}$ Exact Mass: 284,9935), IR: $3363\left(v_{\mathrm{NH}}\right)$, $3139\left(v_{\mathrm{PhH}}\right), 2980\left(v_{\mathrm{CH}}\right), 1589\left(v_{\mathrm{C}=\mathrm{N}}\right), 1538\left(v_{\mathrm{C}-\mathrm{N}}\right), 1522\left(\delta_{\mathrm{CH}}\right), 1485\left(\delta_{\mathrm{CH} / \mathrm{NH}}\right), 1397\left(\delta_{\mathrm{CNH}}\right), 1293$ $\left(v_{\mathrm{N}-\mathrm{C}} / \delta_{\mathrm{NH}}\right), 1104\left(v_{\mathrm{N}-\mathrm{N}}\right), 1081\left(\omega_{\mathrm{NH}}\right), 1066\left(\rho_{\mathrm{NH}}\right), 1006\left(v_{\text {ring }}\right), 921\left(\delta_{\mathrm{CH}}\right), 816\left(v_{\mathrm{CS}}\right), 623\left(\delta_{\mathrm{N}-\mathrm{C}-\mathrm{N}}\right)$. UV-VIS (MeOH, log $\varepsilon$ ): 330 (sh), 319.5 (3.98), 233.0 (3.65), 218 (sh), 202.5 (3.91). 
(E)-2-(4-bromobenzylidene)-N-phenylhydrazinecarbothioamide $\quad$ (3o). $\quad$ Yield: $\quad 68 \%, \quad{ }^{1} \mathrm{H}-\mathrm{NMR}$ (d6-DMSO, $400 \mathrm{MHz}, \mathrm{ppm}): 11.88(\mathrm{~s}, 1 \mathrm{H}, \mathrm{NH}), 10.17(\mathrm{~s}, 1 \mathrm{H}, \mathrm{NH}), 8.13$ (s, 1H, CH), 7.89 (d, $J=8.5 \mathrm{~Hz}, 2 \mathrm{H}, \mathrm{ArH}), 7.63(\mathrm{~d}, J=8.5 \mathrm{~Hz}, 2 \mathrm{H}, \mathrm{ArH}), 7.56(\mathrm{~d}, J=7.6 \mathrm{~Hz}, 2 \mathrm{H}, \mathrm{Ph}), 7.38(\mathrm{t}, J=7.8 \mathrm{~Hz}$, $2 \mathrm{H}, \mathrm{Ph}), 7.22$ (t, $J=7.4 \mathrm{~Hz}, 1 \mathrm{H}, \mathrm{Ph}) .{ }^{13} \mathrm{C}-\mathrm{NMR}\left(d_{6}\right.$-DMSO, $\left.100 \mathrm{MHz}, \mathrm{ppm}\right): 176.6,142.0,139.5$, 133.9, 132.1, 130.0, 128.5, 126.5, 125.9, 123.7. MP: 197-198 ${ }^{\circ} \mathrm{C}[49]$.

\subsubsection{General Procedure for the Synthesis of Thiosemicarbazones 4a-1}

All quinoline-based thiosemicarbazones were prepared according to a recently published procedure [34]. Equimolar quantities of an appropriate thiosemicarbazide and benzaldehyde derivative were mixed and 2 drops of glacial acetic acid were added. The resulting mixture was heated in a microwave reactor at $85{ }^{\circ} \mathrm{C}$ for $12 \mathrm{~min}$ (max microwave power $75 \mathrm{~W}$ ). After cooling, the precipitated soli were filtered and washed with ether and crystallized from methanol. The compounds $\mathbf{4 a}-\mathbf{I}$ studied are presented in Table 2.

\subsection{Lipophilicity Determination Using HPLC (Capacity Factor k/Calculated log k)}

A Waters Alliance 2695 XE HPLC separation module and a Waters Photodiode Array Detector 2996 (Waters Corp., Milford, MA, USA) were used. A Symmetry ${ }^{\circledR} \mathrm{C}_{18} 5 \mu \mathrm{m}, 4.6 \times 250 \mathrm{~mm}$, Part No. WAT054275 (Waters Corp.) chromatographic column was used. The HPLC separation process was monitored using Empower ${ }^{\mathrm{TM}} 2$ Chromatography Data Software, Waters 2009 (Waters Corp.). A mixture of $\mathrm{MeOH}$ p.a. (55\%) and $\mathrm{H}_{2} \mathrm{O}-\mathrm{HPLC}-$ Mili-Q Grade (45\%) was used as a mobile phase. The total flow of the column was $0.9 \mathrm{~mL} / \mathrm{min}$, injection volume $30 \mu \mathrm{L}$, column temperature $30{ }^{\circ} \mathrm{C}$ and sample temperature $10{ }^{\circ} \mathrm{C}$. A detection wavelength of $210 \mathrm{~nm}$ was chosen. A KI methanolic solution was used for the determination of dead time $\left(t_{D}\right)$. Retention times $\left(t_{R}\right)$ were measured in minutes. The capacity factors $k$ were calculated using the Empower ${ }^{\mathrm{TM}} 2$ Chromatography Data Software according to the formula $k=\left(t_{R}-t_{D}\right) / t_{D}$, where $t_{R}$ is the retention time of the solute, whereas $t_{D}$ denotes the dead time obtained using an unretained analyte. $\log k$, calculated from the capacity factor $k$, is used as the lipophilicity index converted to $\log P$ scale. The $\log k$ values of the individual compounds are shown in Tables 1 and 2.

\subsection{Lipophilicity Calculations}

$\log P$, i.e., the logarithm of the partition coefficient for $n$-octanol/water, was calculated using the programs ChemOffice [45] and ACD/LogP [46]. Clog $P$ values (the logarithm of $n$-octanol/water partition coefficient based on established chemical interactions) were generated using ChemOffice software [45]. The results are shown in Tables 1 and 2.

\subsection{Study of the Inhibition Photosynthetic Electron Transport (PET) in Spinach Chloroplasts}

Chloroplasts were prepared from spinach (Spinacia oleracea L.) according to Masarovicova and Kralova [51]. The inhibition of the photosynthetic electron transport (PET) in spinach chloroplasts was determined spectrophotometrically (Genesys 6, Thermo Fisher Scientific, Waltham, MA, USA) using an artificial electron acceptor 2,6-dichlorophenol-indophenol (DCIPP) according to Kralova et al. [52] 
and the rate of photosynthetic electron transport was monitored as a photoreduction of DCPIP. The measurements were carried out in a phosphate buffer $(0.02 \mathrm{~mol} / \mathrm{L}, \mathrm{pH} 7.2)$ containing sucrose $(0.4 \mathrm{~mol} / \mathrm{L}), \mathrm{MgCl}_{2}(0.005 \mathrm{~mol} / \mathrm{L})$ and $\mathrm{NaCl}(0.015 \mathrm{~mol} / \mathrm{L})$. The chlorophyll content was $30 \mathrm{mg} / \mathrm{L}$ in these experiments and the samples were irradiated $\left(\sim 100 \mathrm{~W} / \mathrm{m}^{2}\right.$ with $10 \mathrm{~cm}$ distance) with a halogen lamp $(250 \mathrm{~W})$ using a $4 \mathrm{~cm}$ water filter to prevent warming of the samples (suspension temperature $22{ }^{\circ} \mathrm{C}$ ). The compounds studied were dissolved in DMSO due to their limited water solubility. The applied DMSO concentration (up to 4\%) did not affect the photochemical activity in the spinach chloroplasts. The inhibitory efficiency of the compounds studied was expressed by $\mathrm{IC}_{50}$ values, i.e., by the molar concentration of the compounds that caused a $50 \%$ decrease in the oxygen evolution rate relative to the untreated control. The comparable $\mathrm{IC}_{50}$ value for a selective herbicide 3-(3,4-dichlorophenyl)-1,1dimethylurea, DCMU $\left(\right.$ Diurone $^{\circledR}$ ) was about $1.9 \mu \mathrm{mol} / \mathrm{L}$. The results are summarized in Table 3.

\subsection{In Vitro Antifungal Susceptibility Testing}

The broth microdilution test [53-55] was used for the assessment of the in vitro antifungal activity of the synthesized compounds against Candida albicans ATCC 44859 (CA), Candida tropicalis 156 (CT), Candida krusei ATCC 6258 (CK), Candida glabrata 20/I (CG), Trichosporon beigelii 1188 (TB), Aspergillus fumigatus 231 (AF), Absidia corymbifera 272 (AC), and Trichophyton mentagrophytes 445 (TM). Fluconazole (FLU) was used as the standard since it is a clinically used antimycotic drug. The procedure was performed using a twofold dilution of the compounds in RPMI 1640 (Sevapharma a.s., Prague, Czech Republic) buffered to pH 7.0 with 0.165 mol of 3-morpholinopropane-1-sulfonic acid (MOPS, Sigma, Prague, Czech Republic). The final concentrations of the compounds ranged from 500 to $0.975 \mu \mathrm{mol} / \mathrm{L}$. Drug-free controls were included. The determination of minimum inhibitory concentration (MIC) was performed according to the Clinical and Laboratory Standards Institute (CLSI, formerly NCCLS) reference protocol M27-A2 for yeasts ( $\mathrm{IC}_{80}$ value) and M38-A for moulds ( $\mathrm{IC}_{50}$ value). $\mathrm{IC}_{80}$ and $\mathrm{IC}_{50}$ were defined as an $80 \%$ resp. $50 \%$ or greater reduction in growth in comparison with the control. The values of MICs were determined after 24 and $48 \mathrm{~h}$ of static incubation at $35^{\circ} \mathrm{C}$. The final MICs for T. mentagrophytes, were determined after 72 and $120 \mathrm{~h}$ of incubation. The results are summarized in Table 3.

\subsection{Cell Culture and in Vitro Antiproliferative Activity}

The human colon cancer cell line HCT116 with the wild type $\mathrm{p} 53$ gene $\left(\mathrm{p} 53^{+/+}\right)$were obtained from Maria Sklodowska-Curie Memorial Cancer Center in Gliwice, Poland. Briefly, the cells were seeded in 96-well plates $\left(3 \times 10^{3}\right.$ cells/well) in cellular proliferation assays $24 \mathrm{~h}$ before the addition of the chelators. The assay was performed following a $72 \mathrm{~h}$ incubation with varying concentrations of the agents. Each compound was tested in triplicate in a single experiment with each experiment being repeated 3 times. After $72 \mathrm{~h}$ incubation with the compounds being investigated, $20 \mu \mathrm{L}$ of MTS solution was added to each well $(100 \mu \mathrm{L})$ and incubated for $1 \mathrm{~h}$ at $37^{\circ} \mathrm{C}$. The optical densities of the samples were analyzed at $490 \mathrm{~nm}$. Results were expressed as a percentage of the control. The inhibitory concentration $\left(\mathrm{IC}_{50}\right)$ was defined as the compound concentration necessary to reduce the absorbance to $50 \%$ of the untreated control. The results are summarized in Table 3. 


\section{Conclusions}

A series of fifteen substituted benzylidenethiosemicarbazones and twelve substituted quinolinylvinylthiosemicarbazones were designed, prepared and characterized. The synthesis of these compounds was carried out in microwave conditions, which improves the yield and purity of products isolated. The prepared compounds were tested for their ability to inhibit photosynthetic electron transport (PET) in spinach chloroplasts (Spinacia oleracea L.), for their antifungal activity and for their anticancer activity against human colon cancer. All of the compounds were primarily designed as potential thiosemicarbazone-based iron chelators. All of the compounds discussed showed moderate PET inhibition as well as an antifungal effect. (E)-2-(quinolin-2-ylvinyl)- $N, N$-dimethylhydrazinecarbothioamide (4b) expressed the strongest activity among all of the compounds tested; it was comparable to or more active than fluconazole against Aspergillus fumigatus, Absidia corymbifera, Candida tropicalis and Candida krusei. Compounds $\mathbf{4 b}$ and $\mathbf{4 e}$ expressed micromolar antiproliferative activity better than standard doxorubicin. According to the results, the quinoline nucleus and the $\mathrm{N}, \mathrm{N}$-dimethylhydrazinecarbothioamide chain can be considered as basic structural fragments for high antiproliferative and antifungal activity. Iron chelation was assumed in UV-VIS spectra analysis. According to the results we can concluded that iron chelating ability of the compounds is one of factors necessary for the activity.

\section{Supplementary Materials}

Supplementary materials can be accessed at: http:/www.mdpi.com/1420-3049/17/11/13483/s1.

\section{Acknowledgements}

This study was supported by the grant from the Polish Ministry of Science R 0504303, by the Slovak Grant Agency VEGA Grant No. 1/0612/11 and by Sanofi-Aventis Pharma Slovakia. M.S. was supported by a TWING fellowship and NCN grant DEC-2011/01/N/NZ4/01166. A.M.-W. appreciates the support of the UPGOW fellowship, NCN grant N405/068440 and Dokto-RIS studentship.

\section{References}

1. Wachtershauser, G. Before enzymes and templates: Theory of surface metabolism. Microbiol. Rev. 1988, 52, 452-484.

2. Wachtershauser, G. Groundworks for an evolutionary biochemistry: The iron-sulphur world. Prog. Biophys. Mol. Biol. 1992, 58, 85-201.

3. Danielson, P.B. The cytochrome P450 superfamily: Biochemistry, evolution and drug metabolism in humans. Curr. Drug Metab. 2002, 3, 561-597.

4. Pietrangelo, A.; Schilsky, M. Metal storage disorders. Forward. Semin. Liver Dis. 2011, 31, 231-232.

5. Kalinowski, D.S.; Richardson, D.R. The evolution of iron chelators for the treatment of iron overload disease and cancer. Pharmacol. Rev. 2005, 57, 547-583.

6. Kalinowski, D.S.; Richardson, D.R. Future of toxicology-iron chelators and differing modes of action and toxicity: The changing face of iron chelation therapy. Chem. Res. Toxicol 2007, 20, $715-720$. 
7. Richardson, D.R.; Kalinowski, D.S.; Lau, S.; Jansson, P.J.; Lovejoy, D.B. Cancer cell iron metabolism and the development of potent iron chelators as anti-tumour agents. Biochim. Biophys. Acta 2009, 1790, 702-717.

8. Richardson, D.R.; Tran, E.H.; Ponka, P. The potential of iron chelators of the pyridoxal isonicotinoyl hydrazone class as effective antiproliferative agents. Blood 1995, 86, 4295-4306.

9. Richardson, D.R. The therapeutic potential of iron chelators. Expert Opin. Investig. Drugs 1999, $8,2141-2158$.

10. Yu, Y.; Kalinowski, D.S.; Kovacevic, Z.; Siafakas, A.R.; Jansson, P.J.; Stefani, C.; Lovejoy, D.B.; Sharpe, P.C.; Bernhardt, P.V.; Richardson, D.R. Thiosemicarbazones from the old to new: Iron chelators that are more than just ribonucleotide reductase inhibitors. J. Med. Chem. 2009, 52, 5271-5294.

11. Richardson, D.R.; Baker, E. The uptake of iron and transferrin by the human malignant melanoma cell. Biochim. Biophys. Acta 1990, 1053, 1-12.

12. Richardson, D.R.; Baker, E. Two mechanisms of iron uptake from transferrin by melanoma cells. The effect of desferrioxamine and ferric ammonium citrate. J. Biol. Chem. 1992, 267, 13972-13979.

13. Thelander, L.; Gräslund, A.; Thelander, M. Continual presence of oxygen and iron required for mammalian ribonucleotide reduction: Possible regulation mechanism. Biochem. Biophys. Res. Commun. 1983, 110, 859-865.

14. Yuan, J.; Lovejoy, D.B.; Richardson, D.R. Novel di-2-pyridyl-derived iron chelators with marked and selective antitumor activity: In vitro and in vivo assessment. Blood 2004, 104, 1450-1458.

15. Prasad, T.; Chandra, A.; Mukhopadhyay, C.K.; Prasad, R. Unexpected link between iron and drug resistance of Candida spp.: Iron depletion enhances membrane fluidity and drug diffusion, leading to drug-susceptible cells. Antimicrob. Agents Chemother. 2006, 50, 3597-3606.

16. Holbein, B.E.; Mira de Orduña, R. Effect of trace iron levels and iron withdrawal by chelation on the growth of Candida albicans and Candida vini. FEMS Microbiol. Lett. 2010, 307, 19-24.

17. Nevitt, T. War-Fe-re: Iron at the core of fungal virulence and host immunity. Biometals 2011, 24, 547-558.

18. Kuipers, M.E.; Beljaars, L.; van Beek, N.; de Vries, H.G.; Heegsma, J.; van Den Berg, J.J.M.; Meijer, D.K.F.; Swart, P.J. Conditions influencing the in vitro antifungal activity of lactoferrin combined with antimycotics against clinical isolates of Candida. Impact on the development of buccal preparations of lactoferrin. Acta Pathol. Microbiol. Immunol. Scand. 2002, 110, 290-298.

19. Kuipers, M.E.; de Vries, H.G.; Eikelboom, M.C.; Meijer, D.K.; Swart, P.J. Synergistic fungistatic effects of lactoferrin in combination with antifungal drugs against clinical Candida isolates. Antimicrob. Agents Chemother. 1999, 43, 2635-2641.

20. Spellberg, B.; Ibrahim, A.S.; Chin-Hong, P.V.; Kontoyiannis, D.P.; Morris, M.I.; Perfect, J.R.; Fredricks, D.; Brass, E.P. The deferasirox-ambisome therapy for mucormycosis (DEFEAT Mucor) study: A randomized, double-blinded, placebo-controlled trial. J. Antimicrob. Chemother. 2012, 67, 715-722.

21. Donnelly, J.P.; Lahav, M. Deferasirox as adjunctive therapy for mucormycosis. J. Antimicrob. Chemother. 2012, 67, 201-202.

22. Konstantinovic, S.; Radovanovic, B.; Sovilj, S.; Stanojevic, S. Antimicrobial activity of some isatin-3-thiosemicarbazone complexes. J. Serb. Chem. Soc. 2008, 73, 7-13. 
23. Kizilcikli, I.; Kurt, Y.D.; Akkurt, B.; Genel, A.Y.; Birteksoz, S.; Otuk, G.; Ulkuseven, B. Antimicrobial activity of a series of thiosemicarbazones and their $\mathrm{Zn}(\mathrm{II})$ and $\mathrm{Pd}(\mathrm{II})$ complexes. Folia Microbiol. 2007, 52, 15-25.

24. Kulandaivelu, U.; Padmini, V.G.; Suneetha, K.; Shireesha, B.; Vidyasagar, J.V.; Rao, T.R.KN.J.; Basu, A.; Jayaprakash, V. Synthesis, antimicrobial and anticancer activity of new thiosemicarbazone derivatives. Arch. Pharm. 2011, 344, 84-90.

25. Pervez, H.; Iqbal, M.S.; Tahir, M.Y.; Nasim, F.H.; Choudhary, M.I.; Khan, K.M. In vitro cytotoxic, antibacterial, antifungal and urease inhibitory activities of some $\mathrm{N}_{4}$-substituted isatin-3thiosemicarbazones. J. Enzym. Inhib. Med. Chem. 2008, 23, 848-854.

26. Opletalova, V.; Kalinowski, D.S.; Vejsova, M.; Kunes, J.; Pour, M.; Jampilek, J.; Buchta V.; Richardson, D.R. Identification and characterization of thiosemicarbazones with antifungal and antitumor effects: Cellular iron-chelation mediating cytotoxic activity. Chem. Res. Toxicol. 2008, $21,1878-1889$.

27. Li, Z.-C.; Chen, L.-H.; Yu, X.-J.; Hu, Y.-H.; Song, K.-K.; Zhou, X.-W.; Chen, Q.-X. Inhibition kinetics of chlorobenzaldehyde thiosemicarbazones on mushroom tyrosinase. J. Agric. Food Chem. 2010, 12537-12540.

28. de Aquino, T.M.; Liesen, A.P.; da Silva, R.E.; Lima, V.T.; Carvalho, C.S.; de Faria, A.R.; de Araujo, J.M.; de Lima, J.G.; Alves, A.J.; de Melo, E.J.T.; et al. Synthesis, anti-Toxoplasma gondii and antimicrobial activities of benzaldehyde 4-phenyl-3-thiosemicarbazones and 2-[(phenylmethylene)hydrazono]-4-oxo-3-phenyl-5-thiazolidineacetic acids. Bioorg. Med. Chem. 2008, 16, 446-456.

29. Jampilek, J.; Musiol, R.; Finster, J.; Pesko, M.; Carroll, J.; Kralova, K.; Vejsova, M.; O’Mahony, J.; Coffey, A.; Dohnal, J.; Polanski, J. Investigating biological activity spectrum for novel styrylquinazoline analogues. Molecules 2009, 14, 4246-4265.

30. Jampilek, J.; Musiol, R.; Pesko, M.; Kralova, K.; Vejsova, M.; Carroll, J.; Coffey, A.; Finster, J.; Tabak, D.; Niedbala, H.; et al. Ring-substituted 4-hydroxy-1H-quinolin-2-ones: Preparation and biological activity. Molecules 2009, 14, 1145-1159.

31. Musiol, R.; Serda, M.; Hensel-Bielowka, S.; Polanski, J. Quinoline-based antifungals. Curr. Med. Chem. 2010, 17, 1960-1973.

32. Musiol, R.; Jampilek, J.; Buchta, V.; Silva, L.; Niedbala, H.; Podeszwa, B.; Palka, A.; Majerz-Maniecka, K.; Oleksyn, B.; Polanski, J. Antifungal properties of new series of quinoline derivatives. Bioorg. Med. Chem.2006, 14, 3592-3598.

33. Musiol, R.; Jampilek, J.; Nycz, J.E.; Pesko, M.; Carroll, J.; Kralova, K.; Vejsova, M.; O’Mahony, J.; Coffey, A.; Mrozek, A.; Polanski, J. Investigating the activity spectrum for ring-substituted 8-hydroxyquinolines. Molecules 2010, 15, 288-304.

34. Serda, M.; Kalinowski, D.S.; Mrozek-Wilczkiewicz, A.; Musiol, R.; Szurko, A.; Ratuszna, A.; Pantarat, N.; Kovacevic, Z.; Merlot, A.M.; Richardson, D.R.; Polanski, J. Synthesis and characterization of quinoline-based thiosemicarbazones and correlation of cellular iron-binding efficacy to anti-tumor efficacy. Bioorg. Med. Chem. Lett. 2012, 22, 5527-5531.

35. Green, D.A.; Antholine, W.E.; Wong, S.J.; Richardson, D.R.; Chitambar, C.R. Inhibition of malignant cell growth by 311, a novel iron chelator of the pyridoxal isonicotinoyl hydrazone class: effect on the R2 subunit of ribonucleotide reductase. Clin. Cancer Res. 2001, 7, 3574-3579. 
36. Richardson, D.R.; Sharpe, P.C.; Lovejoy, D.B.; Senaratne, D.; Kalinowski, D.S.; Islam, M.; Bernhardt, P.V. Dipyridyl thiosemicarbazone chelators with potent and selective antitumor activity form iron complexes with redox activity. J. Med. Chem. 2006, 49, 6510-6521.

37. Kalinowski, D.S.; Yu, Y.; Sharpe, P.C.; Islam, M.; Liao, Y.T.; Lovejoy, D.B.; Kumar, N.; Bernhardt, P.V.; Richardson, D.R. Design, synthesis, and characterization of novel iron chelators: Structure-activity relationships of the 2-benzoylpyridine thiosemicarbazone series and their 3-nitrobenzoyl analogues as potent antitumor agents. J. Med. Chem. 2007, 50, 3716-3729.

38. Musiol, R.; Kowalczyk, W. Azole antimycotics-A highway to new drugs or a dead end? Curr. Med. Chem. 2012, 19, 1378-1388.

39. Roche, J.L.; Boyd, P.W.; McKay, R.M.L.; Geider, R.J. Flavodoxin as an in situ marker for iron stress in phytoplankton. Nature 1996, 382, 802-805.

40. Pospisil, P. Enzymatic function of cytochrome b559 in photosystem II. J. Photochem. Photobiol. B 2011, 104, 341-347.

41. Hansch, R.; Mendel, R.R. Physiological functions of mineral micronutrients $(\mathrm{Cu}, \mathrm{Zn}, \mathrm{Mn}, \mathrm{Fe}, \mathrm{Ni}$, Mo, B, Cl). Curr. Opin. Plant Biol. 2009, 12, 259-266.

42. Nouet, C.; Motte, P.; Hanikenne, M. Chloroplastic and mitochondrial metal homeostasis. Trends Plant Sci. 2011, 16, 395-404.

43. Pilon, M.; Cohu, C.M.; Ravet, K.; Abdel-Ghany, S.E.; Gaymard, F. Essential transition metal homeostasis in plants. Curr. Opin. Plant Biol. 2009, 12, 347-357.

44. Serda, M.; Malecki, J.G.; Mrozek-Wilczkiewicz, A.; Musiol, R.; Polanski, J. Microwave assisted synthesis, X-ray crystallography and DFT calculations of selected aromatic thiosemicarbazones. J. Mol. Struct. 2012, in press.

45. CS ChemOffice Ultra, version 12.0; The World's Premier Desktop Chemistry Software. CambridgeSoft: Cambridge, MA, USA, 2008

46. $\mathrm{ACD} / \log P$ version 1.0; Software used for calculating $\log \mathrm{P}$ values. Advanced Chemistry Development: Toronto, ON, Canada, 2006

47. Musiol, R.; Jampilek, J.; Podeszwa, B.; Finster, J.; Tabak, D.; Dohnal, J.; Polanski, J. RP-HPLC determination of lipophilicity in series of quinoline derivatives. Cent. Eur. J. Chem. 2009, 7, 586-597.

48. Taft, R.W. Steric Effects in Organic Chemistry; Newman, M.S., Ed.; John Willey \& Sons: New York, NY, USA, 1956; pp. 556-675.

49. Dimmock, J.R.; Puthucode, R.N.; Lo, M.S.; Quail, J.W.; Yang, J.; Stables, J.P. Structural modifications of the primary amino group of anticonvulsant aryl semicarbazones. Pharmazie 1996, 51, 83-88.

50. Walter, W.; Rohloff, C. Oxidation-products of carbothioamides. 39. Configuration and hindered rotation of 4-monodisubstituted and 4,4-disubstituted thiosemicarbazone S,S,S-trioxides. Justus Liebigs Ann. Chem. 1977, 447-462.

51. Masarovicova, E.; Kralova, K. Approaches to measuring plant photosynthesis activity. In Handbook of Photosynthesis, 2nd ed.; Pessarakli, M., Ed.; Taylor \& Francis Group: Boca Raton, FL, USA, 2005; pp. 617-656.

52. Kralova, K.; Sersen, F.; Sidoova, E. Photosynthesis inhibition produced by 2-alkylthio-6-Rbenzothiazoles. Chem. Pap. 1992, 46, 348-350. 
53. Sheehan, D.J.; Espinel-Ingroff, A.; Steele, M.; Webb, C.D. Antifungal susceptibility testing of yeasts: A brief overview. Clin. Infect. Dis. 1993, 17, 494-500.

54. Clinical Laboratory Standards Institute (CLSI). Reference Method for Broth Dilution Testing of Yeasts: Approved Standard M27-A2; CLSI: Wayne, PA, USA, 2002.

55. Clinical Laboratory Standards Institute (CLSI). Method for Antifungal Disk Diffusion Susceptibility Testing of Yeasts: Approved Guideline M44-A; CLSI: Wayne, PA, USA, 2004.

Sample Availability: Samples of the compounds are available from the authors.

(C) 2012 by the authors; licensee MDPI, Basel, Switzerland. This article is an open access article distributed under the terms and conditions of the Creative Commons Attribution license (http://creativecommons.org/licenses/by/3.0/). 